\title{
Review of Multilevel Inverters for PV Energy System Applications
}

\author{
Ali Bughneda ${ }^{1}\left(\mathbb{D}\right.$, Mohamed Salem ${ }^{1, *(\mathbb{D})}$, Anna Richelli ${ }^{2, *}$, Dahaman Ishak ${ }^{1} \mathbb{D}$ and Salah Alatai ${ }^{1}$ (D) \\ 1 School of Electrical and Electronic Engineering, Universiti Sains Malaysia (USM), Nibong Tebal 14300, Penang, \\ Malaysia; bughneda@student.usm.my (A.B.); dahaman@usm.my (D.I.); salahalatai@student.usm.my (S.A.) \\ 2 Department of Information Engineering, University of Brescia, 25121 Brescia, Italy \\ * Correspondence: salemm@usm.my (M.S.); anna.richelli@unibs.it (A.R.)
}

Citation: Bughneda, A.; Salem, M.; Richelli, A.; Ishak, D.; Alatai, S. Review of Multilevel Inverters for PV Energy System Applications. Energies 2021, 14, 1585. https://doi.org/ 10.3390/en14061585

Academic Editor: Tapas Mallick

Received: 5 February 2021

Accepted: 10 March 2021

Published: 12 March 2021

Publisher's Note: MDPI stays neutral with regard to jurisdictional claims in published maps and institutional affiliations.

Copyright: (c) 2021 by the authors. Licensee MDPI, Basel, Switzerland. This article is an open access article distributed under the terms and conditions of the Creative Commons Attribution (CC BY) license (https:/ / creativecommons.org/licenses/by/ $4.0 /)$.

\begin{abstract}
Over the last decade, energy demand from the power grid has increased significantly due to the increasing number of users and the emergence of high-power industries. This has led to a significant increase in global emissions with conventional energy generation. Therefore, the penetration of renewable energy resources into the power grid has increased significantly. Photovoltaic systems have become the most popular resources as their protentional is enormous, thus, the worldwide installed PV capacity has increased to more than 635 gigawatts (GW), covering approximately $2 \%$ of the global electricity demand. Power electronics are an essential part of photovoltaic generation; the drive for efficient power electronic converters is gaining more and more momentum. Presently, multilevel inverters (MLI) have become more attractive to researchers compared to two-level inverters due to their abilities to provide lower electromagnetic interference, higher efficiency, and larger DC link voltages. This paper reviews multilevel inverters based on their classifications, development, and challenges with practical recommendations in utilizing them in renewable energy systems. Moreover, PV systems with various maximum power point tracking (MPPT) methods have been extensively considered in this paper as well. The importance and the development of a modified multilevel inverter are also highlighted in this review. In general, this paper focuses on utilizing multilevel inverters for PV systems to motivate and guide society to focus on inventing an efficient and economical multilevel inverter that has the combined capabilities of these converters reported in the literature.
\end{abstract}

Keywords: multilevel inverter (MLI); PV system; maximum power point tracking; MPPT; modified MLC converter; leakage current suppression

\section{Introduction}

The huge rate of the global energy demand has led to the high consumption of fossil fuels; thus, the environment has been negatively affected owing to the high emission of greenhouse gasses into the atmosphere. Therefore, renewable energy resources have gained attention and development by generating efficient electric power with almost zero pollution [1]. There are various renewable resources, such as solar energy, wind energy, geothermal, etc. $[2,3]$. Solar radiation contributes largely to the global energy flow. Out of the total amount of solar radiation radiated from the sun, more than 100,000 TW reach the Earth's surface after reflection and absorption [4]. This amount of free energy has the potential to make solar energy a significant contributor to renewable energy sources [5]. Despite this availability, the global contribution of solar energy to the energy network is still small [6,7]. Significant improvements have indeed been made in the deployment of PV systems over the past three decades, yet certain challenges are still facing solar technologies and, as such, these technologies are yet to compete favorably with the other energy sources, such as fossil fuels, in the energy market. Among these challenges are the high capital cost, intermittency, and modest conversion efficiency of solar technologies [8]. From a technical and scientific perspective, there is an urgent need to develop new technologies that can offer greater conversion efficiencies at a lower production cost as this will improve the 
entry of solar technologies into the energy market. Several studies have been dedicated to finding solutions to these problems for better reliability, performance, and competitiveness of solar-based energy technologies [9-11]. PV cells are used in solar based technologies for the conversion of the solar energy into electrical energy. The components of a system for solar energy conversion include the PV cells, the power converters, and the control unit for the regulation of the power extracted from the PV cells (see Figure 1) [2]. For the efficient harvesting of power from renewable energy sources, various control techniques, power converter topologies, and power tracking methods have been developed [12,13]. Yet, more studies are still focusing on ways of integrating renewable energy sources into the power grid for better efficiency. In this regard, more attention is given to power converters and their controls owing to their vital role in power conversion and output power regulation from these resources. Normally, attention is given to DC/DC converters as the front-end stage of the renewable energy sources' integration into the DC grid. At this stage, the major requirement is the high efficiency because of the associated variabilities with the output voltage of the renewable energy sources, such as wind and PV energy sources. Therefore, there is a need to ensure the adaptation of the DC/DC front-end stages to such variation so that they can operate maximally. Mostly, the two-level inverters are deployed in small-scale industries and utility applications [14] as they are not suitable for high-power applications due to their production of high voltage stress, low-efficiency operation, and high temperature. Hence, multilevel inverters are mostly used in large-scale high-power grid-connected renewable energy systems [15]. Scholars are focusing more on multilevel inverters due to their low switching losses, high voltage operation capability, low Electro-Magnetic Interference (EMI) output, high efficiency, and good power quality performance (low THD output) due to multiple level output waveform [16].

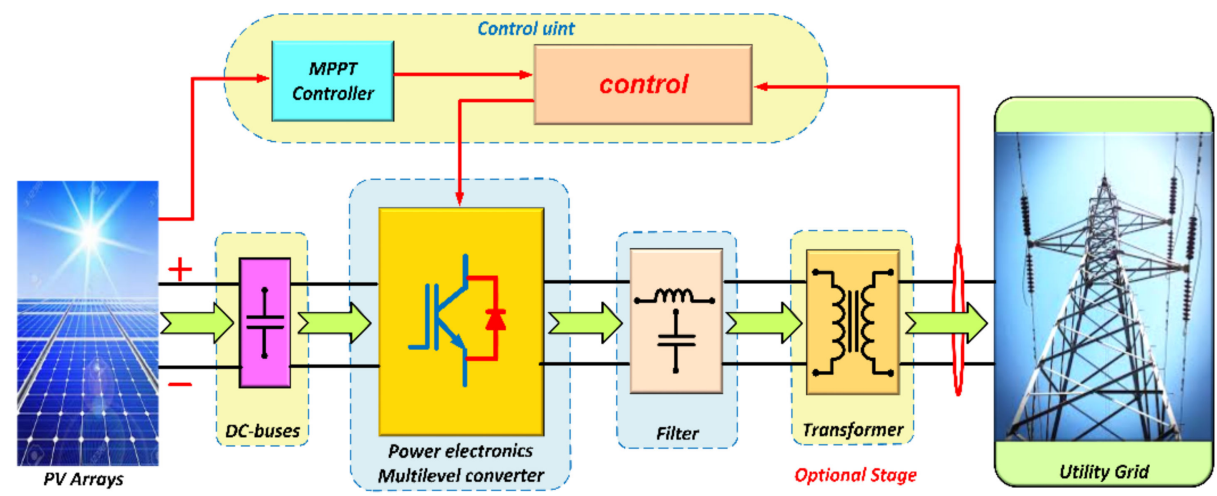

Figure 1. A photovoltaic (PV) system with power electronics and the needed control.

The first attempt at multilevel converters was made in 1975 [17], starting with the three-level converters [18] and subsequently advanced to several multilevel converters topologies [19-21]. However, the MLI is based on the concept of using several DC sources and numerous low-power rated semiconductor switches for the synthesis of a stepped voltage waveform; these are aimed at achieving greater levels of power generation. Various energy sources can be used as multiple-input DC sources, such as batteries, solar PV panels, capacitors, and fuel cells. Then, algorithms are used to control the power switches when combining these multiple DC sources to get a high output voltage [16,22]. There are various industrial applications of MLI topologies, such as in grid-connected renewable energy systems (RES) where it is used as an advanced power converter topology. Currently, the trends in MLIs are mainly focusing on the reduction of the switch count, gate driver circuits, and DC supplies to improve fault tolerance and power quality, thereby making the system cost-efficient for grid-connected RES [23].

Several advance have been witnessed in MPPT controllers in the areas of their accuracy, reliability, efficiency, simplicity, and tracking speed. Normally, the optimal MPPT algorithm exhibits fast speed and less oscillation about the PPP; it goes along with the rapid changes in 
output power. Several applications of MPPT control techniques are currently available [24]; however, the major application of these controllers is either in tracking the MPP under uniform irradiance or tracking a PV system with MMPP. For any given PV system, the MPP must be unique and must not rely on a complex algorithm to be tracked. Note that there could be some abnormal phenomena in some cases, such as partial shading (PS), which is among the commonest factors with steric effect on the extracted power from PV systems [25]. It is implicated in cases of multipeak points that generate MMPP [26] and global maximum power point (GMPP) [27]. A traditional MPPT algorithm that is under PS normally exhibits low efficiency [28].

Several classifications are available in the literature for the indexing of MPPT controllers [29-31]. These classifications are based on different conditions, such as the tracking techniques, modernity, and sensing implementation. Generally, MPPT is classified into the conventional, advanced (soft computing), and hybrid methods. Regarding the conventional methods, they are generally simple but cannot differentiate local peaks from global peaks during PS; hence the causes of low efficiency [28]. Due to their higher efficiency, they require advanced tracking methods to be tracked [32]. Being that the use of the conventional and advanced methods alone is associated with numerous limitations, studies have proposed the hybrid methods as a combination of both methods to overcome these limitations [33]. However, determining the best MPPT method to be used is still an issue. Hence, more studies are still ongoing in the area of MPPT techniques to arrive at a system with better performance in terms of the system cost, the ease of implementation, the tracking efficiency, and the adaptability to different PV systems.

The paper is organized thus: Section 2 presents the classification of MLIs and discussion on the structure and working principle of three major MLI topologies with the comparison between them based on the advantages and disadvantages. Section 3 presents the modified multilevel converter as a case of study and how it was favored among others. Section 4 provides an overview of utilized multilevel inverters in various renewable systems. Photovoltaic (PV) systems and their characteristics, followed by a concise classification of the applied MPPT methods, are highlighted in Section 5. The multilevel inverters utilized for PV systems are also considered in Section 6. In Section 7, the challenges and future work areas are presented, while Section 8 summarizes the study.

\section{Multilevel Inverters (MLIs)}

These days, MLIs are being deployed in power systems because of their ability to meet the demand in power quality and power rating, as well as their reduced level of harmonic distortion and electromagnetic interference. There are several advantages of an MLI over the traditional two-level inverters where high switching frequency PWM is used [34,35]. MLIs are currently being considered as an industrial solution for high power quality and dynamic performance demanding systems, spanning through a power range of 1 to $30 \mathrm{MW}$ [36]. Hence, MLIs are ideal for use in high voltage applications because they can generate low THD output voltage waveforms and can generate higher voltages with a limited device rating [37]. The sources of sustainable energy, such as PV cells, fuel cells, and wind can broadly interact with a multilevel converter system [38]. Mostly, the type of control algorithm utilized in the PWM of MLIs determine their operations, efficiency, power ratings, and application [39]. Several studies have proposed various MLI topologies over the last few decades [40-43]. Figure 2 shows the classification of the MLIs into two main groups based on the number of employed DC sources in their topology. Until now, the most commonly used topologies in the industries are the neutral point clamped (NPC) or diode clamped, the flying capacitor (FC), and the cascaded H-bridge (CHB) [44-46].

\subsection{Cascaded H-Bridges MLI}

The CHB-MLIs are produced from the serial connection of numerous single-phase $\mathrm{H}$-bridge inverters with separate DC sources (SDCS). Each H-bridge consists of four unidirectional power switches and one DC source as shown in Figure 3 [22]. Each inverter level 
is programmed to produce three voltage outputs $(+\mathrm{Vdc}, 0$, and $-\mathrm{Vdc})$ via the connection of the DC source to the AC output; the desired output is achieved by connecting the four switches (S1-S4) in different manners. Switching the $S 1$ and $S 4$ switches to the ON position generates the $+\mathrm{Vdc}$ output, but when $S 2$ and $S 3$ are in the ON position, $-\mathrm{Vdc}$ output is produced. To produce the 0 output voltage, either $S 1$ and $S 2$ or $S 3$ and $S 4$ must be in the ON position. A serial connection of the AC outputs of the full-bridge inverter is made in such a way that the generated voltage waveform will represent the sum of the outputs of all the inverters. In a cascade inverter, $m=2 s+1$ is used to represent the number of output phase voltage levels, with s being the number of different DC sources [47]. This topology requires a smaller number of components when compared to DCMLI and FCMLI because it does not have clamping diodes and clamping capacitors. In addition to that, it is free from the voltage balancing problem because it does not contain DC link capacitors $[23,48]$. On the other hand, the multiple DC sources can be replaced either by separate renewable energy sources with separate converters or by single renewable energy sources with multioutput converters where the voltage balancing is the major concern.

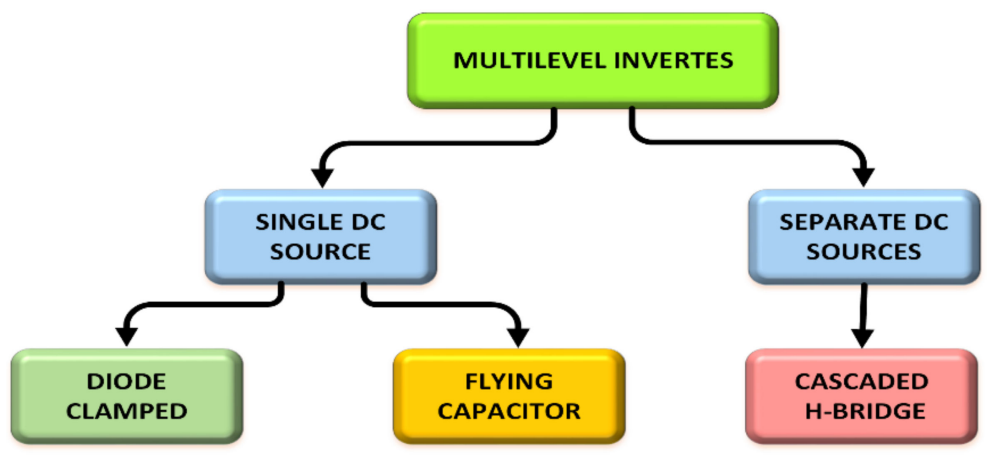

Figure 2. Multilevel inverters (MLIs) and their classification.

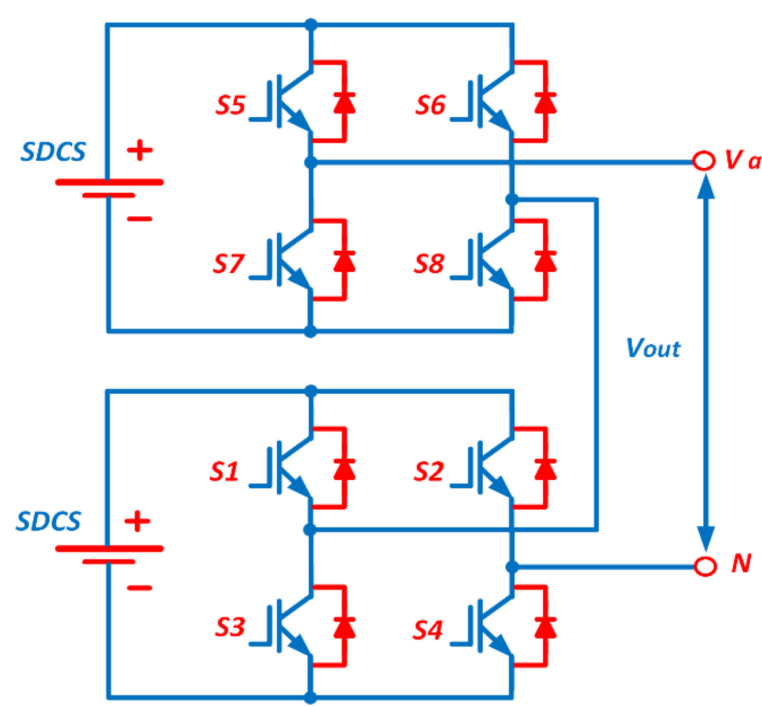

(a)

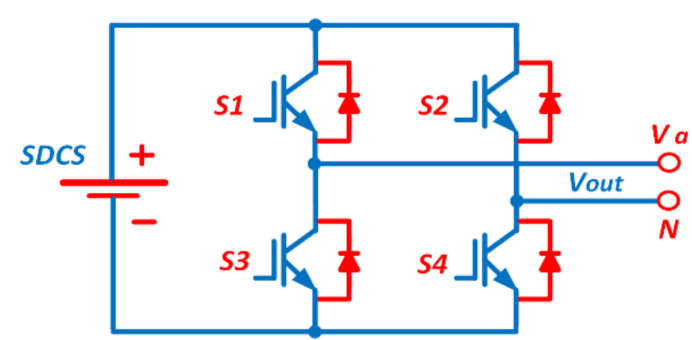

(b)

Figure 3. (a) Five-level CHBMLI topology, (b) three-level CHBMLI topology.

Proposals have been made for the use of multilevel cascaded inverters in applications for static var generation, as well as their usage as an interface with RES [49]; they have also been proposed for use in battery-powered applications. A cascade inverter can also be used for static var compensation via direct connection in series with the electric system. They are suitable for the hooking of RES to the AC grid as they need separate DC sources 
when used in fuel cells and photovoltaics [50]. They have also been proposed to be used in electric vehicles as the main traction drive because in such applications several batteries or ultracapacitors serve as SDCSs [51]. The structure of this topology is flexible and can be used in different number of inverter levels. The generation of the different output voltages is achievable via the application of different ratios of the DC sources and reducing the inner voltage levels-related switching redundancy. Transformer-dependent CHBMLIs are developed to reduce the need for independent DC sources; it is like the CHBMLI structure but differs by the serial connection of the output voltage of the isolation transformer [52].

\subsection{Flying Capacitor MLI}

There are close similarities in the topologies of the FCMLI and DCMLI just that the FCMLI relies on the use of floating capacitors rather than clamping diodes. For the FCMLI, the magnitude of the voltage steps in the output waveform is a direct function of the voltage variation occurring in the adjacent capacitors [53]. The FCMLI topology for the ' $\mathrm{m}$ ' level inverter is comprised of ' $m-1^{\prime}$ DC link capacitors count. Figure 4 is a schematic of the 3-level FCMLI topology which contains four unidirectional power switches and a flying capacitor, in addition to a DC supply with two capacitors for obtaining voltage levels ( $V d c / 2$, $0,-V d c / 2$ ). Switches $S 1$ and $S 2$ must be in the ON position to generate the positive polarity output voltage while $S 3$ and $S 4$ are switched $O N$ for the negative polarity output voltage. Switches $S 1$ and $S 3$ or $S 2$ and $S 4$ are turned on to generate the 0 level output voltage. In the FCMLI, the voltage synthesis is more flexible compared to that of a DCMLI. When there are more than five levels, the problem of voltage balancing can be addressed by making a proper selection of the switching combination [34]. One major advantage of this topology is that the reactive and active power can be controlled [53] while its major drawback is in the use of several capacitors, which makes the system expensive and difficult to assemble. Furthermore, the switching frequency losses in such arrangements are high in real power transmission [54].

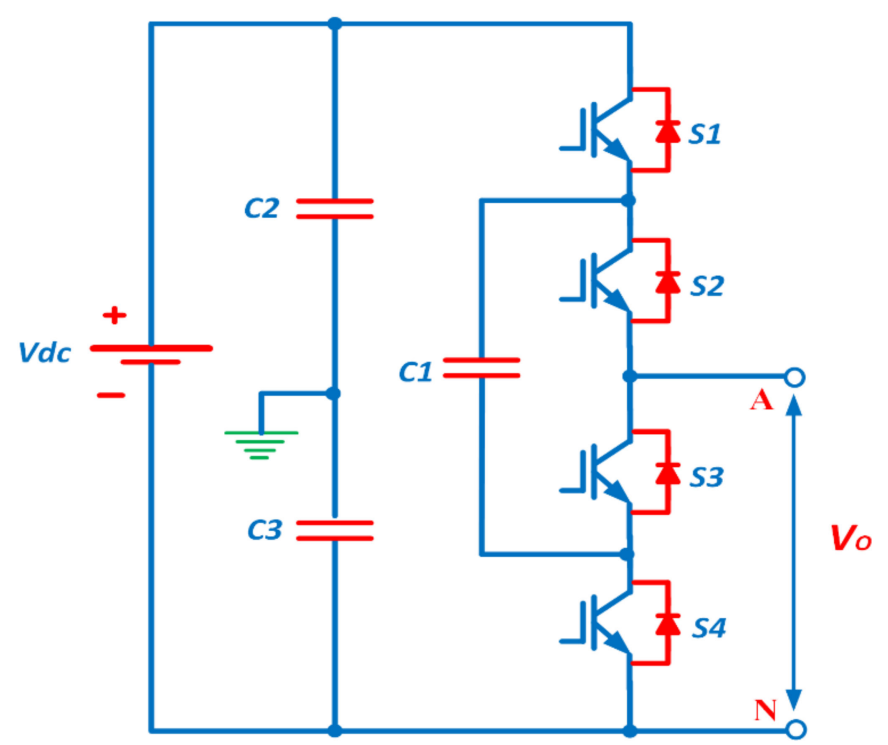

Figure 4. Three-level flying capacitor MLI topology.

\subsection{Diode Clamped MLI}

This type of inverter, also called a neutral point clamped inverter (NPC), was invented in 1981 by Nabae et al. [18]. Figure 5 depicts the DCMLI topology, which is used to generate an output voltage with three levels. The configuration for this topology contains four unidirectional power switches, two diodes, and two capacitors. The clamping diodes are connected in series to share the blocking voltage. In this topology, the output voltage is of three levels, which are $V d c / 2,0$, and $-V d c / 2 ; V d c / 2$ is generated by keeping $S 1$ and 
$S 2$ switches ON while $S 3$ and $S 4$ are switched to ON to generate $-V d c / 2$. Switches $S 2$ and $S 3$ are turned on to produce the 0 level voltage. During the passage of the equivalent voltage through the DC link capacitors, it is expected that each active switching device has voltage stress that is clamped to the voltage of each capacitor through diode clamping [54]. In a real application, the blocking voltage is shared by serially connecting the clamping diodes. Then, only a voltage level of $V /(m-1) d c$ is required to be blocked by each active device. For reverse voltage blocking, the voltage ratings of the clamping diodes must vary. If operating the DCMLI under the PWM technique, the major issue with the design in high voltage applications is the diode reverse recovery of these clamping diodes [55].

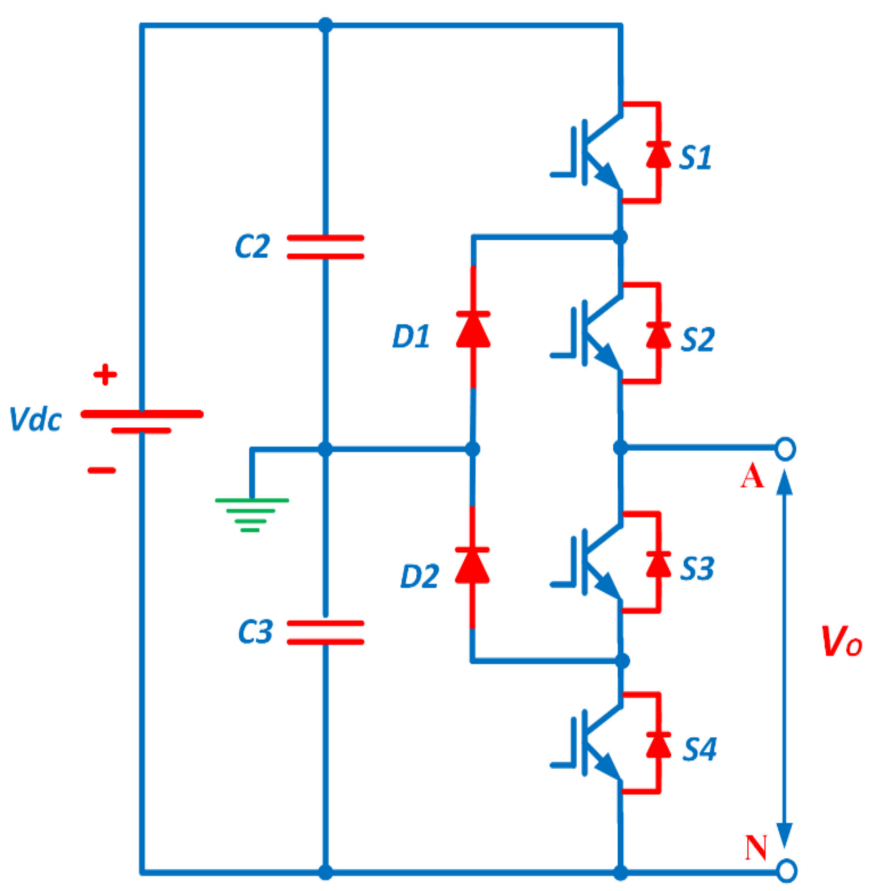

Figure 5. Three-level diode-clamped MLI topology.

The DCMLI, in comparison to the other multilevel converter topologies, has a greater industrial application due to its high-power delivery capability, simplicity, and efficiency. It has found application in Static VAR Compensators (SVC), high voltage system interconnections [55,56], and variable speed motor drives. The need for a capacitance is annulled in the DCMLI converter as the components share a common DC bus. Hence, it can be used in high voltage back-to-back interconnection, adjustable speed drives, and other back-to-back topologies. However, the problems of this converter include difficulty in single inverter real power flow due to discharging or overcharging of the DC level without adequate control [57], as well as the issue of balancing and stabilizing the capacitor DC voltage in the DC link [41].

\subsection{Comparison between CHB-MLI, FC-MLI, and DC-MLI Topologies}

In this section, a comparison between the three main MLI topologies, called the classical topologies, was made in terms of the advantages and disadvantages, as illustrated in Table 1. 
Table 1. Advantages and disadvantages of the classical topologies (DC-MLI, FC-MLI, and CHB-MLI).

\begin{tabular}{|c|c|c|}
\hline Types of MLI & Advantages & Disadvantages \\
\hline $\begin{array}{c}\text { DC-MLI } \\
{[18,35,41,55,57-61]}\end{array}$ & $\begin{array}{l}\text { - } \quad \text { A good option for industrial applications. } \\
\text { - } \quad \text { Exhibits high fundamental frequency } \\
\text { switching efficiency. } \\
\text { - } \quad \text { Can precharge the capacitors as a group. } \\
\text { - } \quad \text { Reduces the number of required DC sources. } \\
\text { - } \quad \text { Appropriate for fault-tolerant application. } \\
\text { The use of neutral clamping switches can solve } \\
\text { the issue of voltage balancing and uneven loss } \\
\text { sharing between the switching devices in } \\
\text { neutral point clamped (NPC) converters. }\end{array}$ & $\begin{array}{l}\text { - The complexity of voltage balancing circuit. } \\
\text { The unequal share of losses between inner } \\
\text { and outer switches. } \\
\text { Increased number of clamping diode as the } \\
\text { level increased. }\end{array}$ \\
\hline $\begin{array}{c}\text { FC-MLI } \\
{[22,35,41,57,59,62,63]}\end{array}$ & $\begin{array}{l}\text { - } \quad \text { Reduces the number of required DC sources. } \\
\text { - } \quad \text { Phase redundancies are available for balancing } \\
\text { the voltage levels of the capacitors. } \\
\text { - } \quad \text { Appropriate for fault-tolerant application. } \\
\text { - } \quad \text { Real and reactive power flow can be controlled } \\
\text { Noed for filters to reduce harmonics. }\end{array}$ & $\begin{array}{l}\text { - The complexity of voltage balancing circuit. } \\
\text { - } \quad \text { Requires numerous capacitors for high levels. } \\
\text { - } \quad \text { power losses and switching frequency for real } \\
\text { - High installation cost. }\end{array}$ \\
\hline $\begin{array}{c}\text { CHB-MLI } \\
{[22,23,59,64-67]}\end{array}$ & $\begin{array}{l}\text { - } \quad \text { Modular and simple structure. } \\
\text { - } \quad \text { Requires only unidirectional switches. } \\
\text { - } \quad \text { Appropriate for fault-tolerant application. } \\
\text { - } \quad \text { Potential of electric shock is reduced due to the } \\
\text { separate DC sources. } \\
\text { - Asymmetric source configuration can } \\
\text { be employed. } \\
\text { - Can be implemented as a single DC } \\
\text { source configuration. }\end{array}$ & $\begin{array}{l}\text { - } \quad \text { Less number of output voltage levels. } \\
\text { - } \quad \text { Requires more number of gate driver circuits. } \\
\text { Requires several DC sources to increase the } \\
\text { output voltage. } \\
\text { Limited to certain applications where } \\
\text { separate DC sources are available. } \\
\text { - Switches have to bear blocking voltage equal } \\
\text { to the input voltage value. } \\
\text { - } \quad \text { Loss of modularity (asymmetric } \\
\text { source configuration). } \\
\text { Implement cost is high (asymmetric } \\
\text { - Source configuration). } \\
\text { Switches are differently voltage rated } \\
\text { (asymmetric source configuration). }\end{array}$ \\
\hline
\end{tabular}

\section{Modified Multilevel Inverter}

Although MLIs have various advantages over other inverters, they have been extensively tested and developed to produce better efficiency by considering sizes and cost with all types and different voltage levels obtained. Thus, a modified multilevel inverter was invented by modifying MLI configurations and designing MLI with less count of power switches. With the reduced number of switched MLIs, the system has the advantages of cost-effectiveness, lower component count, and less space occupancy [23]. Considering this, the cascaded H-bridge MLI was adopted as a case study [68-71] because of its lower component requirement compared to the MLI topologies. A further modification was done on the CHBMLI framework to achieve a five-level output for single phase usage using a lower number of switching components rather than the required eight switches in the conventional design as depicted in Figure 6. Moreover, the system is completed by adding a filter at the output of the inverter for greater THD reduction. The study by [72] investigated the relationship of the THD with changes in the switching frequencies and inverter levels; the study found the switching frequency of $6 \mathrm{kHz}$ and the seven-level inverter as the arrangement generating the lowest THD. In this case, a five-level design was selected because of its lesser circuit complexity and less THD. Figure 6a presents the general structure of MLI while the modified version used in this study is shown in Figure 6b. According to [36], MLIs are modular and easy to design [36]; they are suitable for use in high power and high voltage systems [73]; their simple configuration allows the generation of a higher voltage without the need for high rating components since the multilevel topology ensures that the overall device stress is distributed among the 
respective components [74,75]. Hence, MLIs can be used for $10 \mathrm{kV}$ rated DC-link voltage inverters. There is also a significant decline in the switching losses. The total rated load losses can also be reduced by $60 \%$ using a five-level inverter. The use of higher number of inverter levels decreases the THD of the output, thereby increasing the signal quality [73].

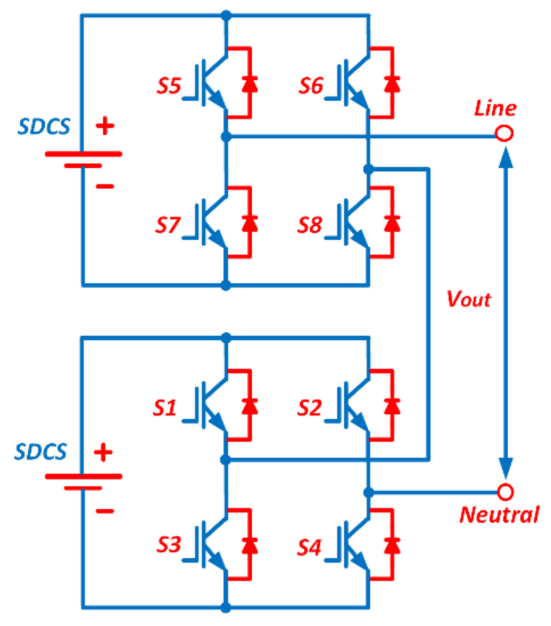

(a)

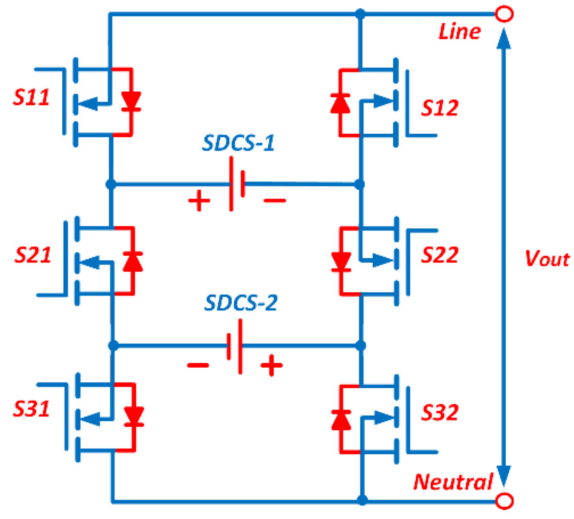

(b)

Figure 6. (a) Schematic of the MLI topology where each 4-switch block is considered an H-bridge. (b) The modified structure of a 5-level inverter that uses 6 switches instead of 8 .

The extent of work done on this inverter type recently portrays their importance in this field. For instance, reference [76] suggested a three-phase five-level inverter that uses six switches, while reference [77] developed a single-phase inverter that has six switches per inverter cell. In this system, the ratings of two of the switches differed from those of the other four (four switches are designed to withstand $400 \mathrm{~V}$, while the others are exposed to $200 \mathrm{~V})$. Hence, two different switch ratings are needed in this system. Furthermore, the study by [78] proposed an 11-level inverter that has 14 switches, while a system with fewer switches was presented by [73]; this system relies on low rating switches and exhibited the expected performance level via cross-connection of the switches. The study also evaluated this approach on an 11-level inverter system. Various studies [79-83] have presented similar MLI architectures with a reduced number of switches. A topology that can combine individual battery cells that are serially connected to achieve multiple voltage levels has also been presented; the system was developed with a reduced number of switches via the intelligent modification of the cell connection. This topology can also utilize capacitors and other DC sources and could be used in grid-connected PV systems [84]. Single-phase MLIs have been connected with grid-connected PV systems in the studies by $[85,86]$. The study by [87] presented another topology with a lower number of switches (six switches); the system was designed by altering the polarities of the DC source as required. The performance of the system was evaluated as well on a five-level single-phase inverter.

\section{Multilevel Inverters in Renewable Energy System Applications}

Due to the MLI's capabilities of producing high-quality voltage waveforms through low switching frequency operation, they are thus preferred for high and medium power applications [41,88]. MLIs have widely used in various applications such as power supplies (PSs) applications; renewable energy systems (RESs) such as photovoltaic (PV) systems, wind energy conversion systems (WECS) and fuel cells (FC); electric vehicles (EV); induction heating $(\mathrm{IH})$ and numerous other fields. Many MLI topologies have been integrated with RESs in grid-connected systems for the addition of the power generated by the RESs to the grid [89]. 


\subsection{Wind Energy Conversion Systems (WECS)}

An attempt to the use of a CHBMLI topology to interface split winding wind alternators (SWAs) to the grid was made by [90]. The experimented SWA-CHBMLI system was found efficient in interfacing a large wind turbine to the grid; the system also achieved better power quality at the PCC, thereby making the system more efficient. In recent years, scholars have been paying attention to MLIs designs with fewer numbers of gate drivers and switches to reduce the required installation space and the cost of MLIs. A hybrid modular multilevel converter was presented by [91] for the connection of large wind turbines to the grid. The system is a promising converter topology on the grid-side of a back-to-back connected full-scale converter of a WECS since it combined MMC and HB module features. It can improve the reliability of the entire WECS. A study by [92] presented a novel two-stage CSD multilevel system that used a lower number of switches to achieve a high number of voltage levels; the system also addressed the issue of high voltage spikes under R-L loads as the system has a path for the reverse load currents. The system was considered suitable for integration in medium-voltage renewable energy systems. The use of a modular cascaded MLI in a fault-tolerant distributed control system has been evaluated by [93] for the integration of wind turbines to the grid. The inverter was found capable of synchronizing with the grid frequency without any damage to the in-coming currents, which is a necessary condition after clearing a grid fault or when first connecting to the grid.

\subsection{Fuel Cells (FC)}

A hybrid cascaded MLI was designed and developed by [94] for fuel cell application by using the variable frequency inverted sine wave carrier modulation technique (VFISPWM). This modulation technique aims to improve the output voltage while giving low THD and reduced switching losses. Another work by [95] came up with a fuel cell-based system with H-bridge DC / AC inverter and a three-level boost converter. To make sure the system operates in stable conditions, two feedback control loops were designed and added to the system. The developed multilevel DC-DC converters can be used in RESs for power generation at a reduced cost. A hybrid cascaded multilevel inverter CMLI has been proposed by [96] for fuel cell power conditioning systems. The developed system can generate high voltages at higher speeds with a high conversion efficiency while ensuring low switching losses. The developed system can be used in high-power fuel cell systems. The study by [97] reported the development of an open-loop FC-based energy system interfaced with CHBMLI. The system was evaluated for performance under different loading conditions and from the results, the system performed better than the conventional inverter-based systems and was considered appropriate for use in FC based energy system where there is a need for more flexibility and power handling capability. A proton exchange membrane fuel cell interfaced with five-level diode clamped MLI was presented by [98]. This arrangement was intended to reduce harmonic distortion and increase system efficiency. The study by [99] presented a system for energy delivery from a fuel cell to the grid; the system was equipped with a single-stage multilevel current-source inverter (MCSI) for energy provision and for increasing the power quality in the grid. The study found the developed system as an alternative in smart grids or distributed generation systems because it can generate active power while reducing the line current harmonics and compensating the power factor.

\subsection{Electric Vehicles (EVs)}

The cascaded H-bridge converters have been used by [100,101], for the balancing of the voltage of battery cells. In the studies, each battery cell was controlled using one H-bridge cell while a separate control of the charging and discharging cycles ensured voltage balance. The converter generated multilevel output voltage, and this is considered suitable for motor drives. A hybrid cascaded multilevel converter was proposed by [102]; the proposed system was for battery energy management and EV motor drives were 
proposed. The system was capable of balancing the terminal voltage or SOC between the employed battery cells; hence, it exhibited a good fault-tolerant characteristic, which boosts the reliability of the system. The study by [103] presented a new modular multilevel topology that contains electrochemical cells; the system was proposed for use in battery electric vehicles. The multilevel nature of the output voltages significantly reduced the THD of the motor currents and minimized motor power losses. Hence, the system can be used for the elimination of the balancing circuits of the battery pack of electric vehicles. The performance of modular multilevel converters that contain battery cells has been evaluated by [104] in electric vehicles for traction drive. The system significantly reduced the motor current distortion, thereby improving the motor efficiency. MMC offers better reliability compared to two-level inverters; this is why the proposed converter is most suitable for urban use of the electric car. A study by [105] reported the use of the CMLI in the battery energy storage system (BESS). The performance of the system was positive during the charging, discharging, and transient operating conditions. A hybrid CMLI was proposed by [106] based on three-level (TL) cells for the provision of more voltage levels and to satisfy the requirement of the motor drive in EVs. The proposed system produced higher voltage levels when compared to the traditional topologies at the same number of battery modules.

\subsection{Induction Heating (IH)}

The provision of induction heating power simultaneously at two frequencies using multilevel converters has been proposed by [107]; this was aimed at achieving higher efficiency, better control, greater reliability, and reduced electromagnetic interference. A CMLI has been used by [108] to accelerate high frequency and high-power application of induction heating power supply. The study by [109] developed a new IH power supply system based on a multilevel neutral point clamped inverter (MNPCI). The system reduced the DC link voltage by half, thereby reducing the switching losses and improving the system efficiency. Furthermore, reference [110] reported the use of MNPCI in an IH system with maximum harmonic control. The system achieves natural switching with the highest heating power efficiency and lowest harmonic distortion. In [111]. A modular MLC has been applied in the tundish induction heating power supply (TIHPS) for the heating of molten steel. In [112], the multilevel neutral point clamped inverter (MNPCI) has been used as part of a super frequency induction heating power supply system with an optimum control algorithm. Thus, a new multilevel neutral point clamped inverter was developed as a component of the IH system.

\section{Photovoltaic Systems (PVs)}

Much attention has been given to PV-based power generation due to its numerous advantages, such as ease of allocation, longer life, absence of noise, lack of pollution, lesser installation time, high mobility and components' portability, and ability to produce power output that can meet peak load requirements. Hence, PV arrays have found many industrial applications, such as in battery recharging systems, solar hybrid vehicles, satellite power systems, solar-based water-pumping machines, etc. For this reason, many countries are investing heavily in renewable energy-based projects. However, there are certain problems associated with PV generation systems, such as low conversion efficiency and interference from climate conditions. The power of PV cells is directly a function of the solar intensity/radiation but depends less on the temperature [113]. A complete PV system is comprised of solar panels, batteries, DC-DC voltage converters, and controllers. The work of the DC-DC voltage converters is to match the load characteristics with the characteristics of the solar panels. There are three categories of DC-DC voltage converters, namely boost, buck, and buck-boost converters. The expected voltage level determines the section of the appropriate form of DC-DC voltage converter. Batteries are used to make the PV systems act as the real feeder source such that it is possible to achieve constant voltage levels that correspond to different loads. Another use of the battery is for power saving and as temporary compensation for power fluctuations. A solar panel is made up of 
several PV cells that are connected either in series or parallel or as series-parallel external connections [114].

The photovoltaic power characteristics are nonlinear, as illustrated in Figure 7. The characteristics of a PV cell are analyzed using parameters such as open-circuit voltage (Voc) and short-circuit current (Isc). Regarding the Isc, it is the maximum value of the current produced by a cell; this parameter is sensitive to irradiance. On the other hand, the Voc is the maximum value of the voltage that a solar cell can produce at zero current [114]. There is the equivalent circuit generic model to represent PV cells. Which has a single diode with series resistance and a shunt resistance as shown in Figure 8. The current source represents photon-generated current (Iph) by PV, which is proportional to the solar irradiation. The resistance (Rs) represents the contacts and connections-related losses, while the leakage currents in the diode are represented by parallel resistance (Rsh) [113,115].

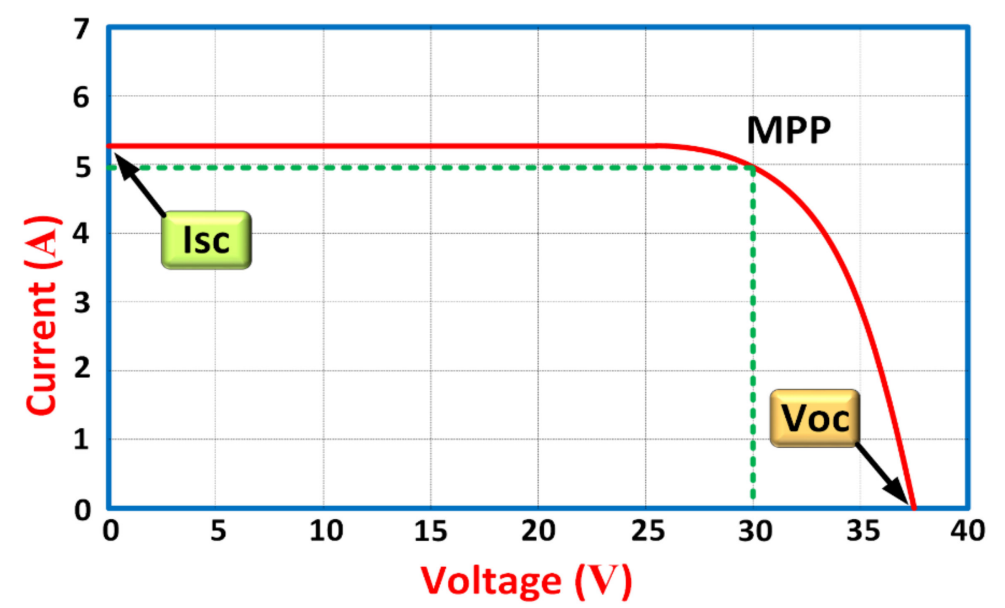

Figure 7. The current I- voltage V characteristics of a PV module.

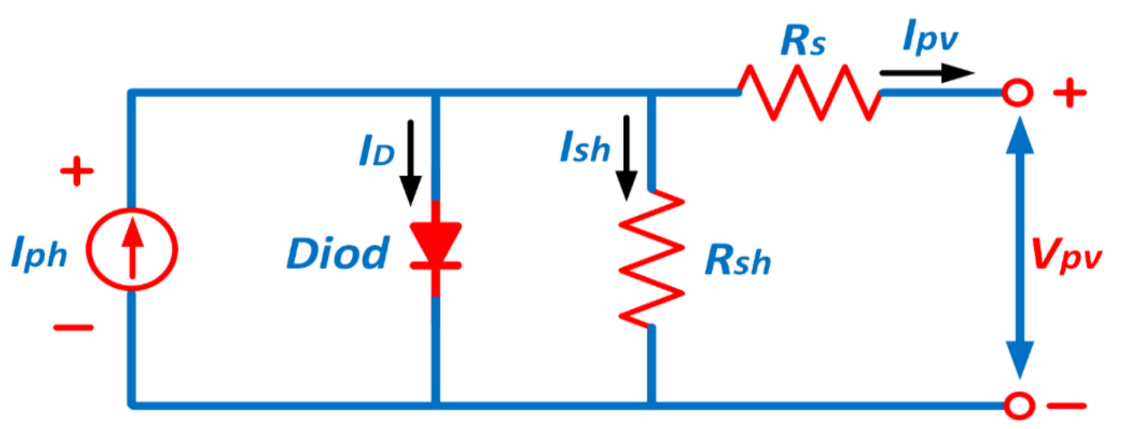

Figure 8. The equivalent circuit of PV cell.

\subsection{Maximum Power Point Tracking (MPPT) Techniques}

Significant improvements have been made recently towards improving the capability of PV energy in meeting the ever-increasing global energy demand. However, it is still a challenge to efficiently deploy and use PV systems due to the high initial cost of the PV materials. Another factor that limits the advancement of PV systems is the low conversion efficiency associated with the PV module; hence, studies are focusing on the integration of power converters with MPPT capability into PV systems to ensure optimum energy harvesting from the available environmental conditions [115]. Owing to the variations in weather, the MPP can lose stability based on the weather conditions (temperature and irradiation); this could lead to great power losses when operating at points that are far from the MPP. Therefore, the MPP must be tracked in any condition to ensure that the maximum available power is generated by the PV panels. Note that this is a function of the PV parameters and the weather conditions [29]. For a better efficiency of PV systems, 
MPPT controllers have often been deployed to track the PPP. Hence, MPPT controllers have received much attention as an important component of the PV system that requires optimization. Being that different algorithms are used in these controllers, they vary in their performance, tracking speed, efficiency, and complexity. They can be used to track the MPP under uniform irradiance for a specific MPP or the tracking of the PV system with MMPP [31].

The evidence in the literature suggests the availability of several MPPT algorithms, with each approach having its limitations, specifications, and application. The classification of MPPT methods is based on different forms, such as the sensing implementation, tracking technique, and contemporary. These major classifications are further subclassified based on different factors, working principles, or implementation. They can be generally classified into three main types as follows:

- Conventional MPPT methods.

- Advanced (soft computing) MPPT methods.

- Hybrid MPPT methods.

\subsubsection{Conventional MPPT Methods}

These were the early entrants; hence, they are the most popular, with the major advantages of being simple and easy to implement. These methods can only track single MPPs under uniform irradiance $[28,116]$; hence, they are commonly applied in perturb and observe (P\&O), incremental conductance (INC), parasitic capacitance (PC), and Hill Climbing (HC) [117-120]. Some of the shortfalls of these techniques include not being able to work under PSCs because they cannot easily observe the GMPP under PSCs despite receiving the required GMMPT a long time ago with low tracking accuracy and large oscillation. So, they normally exhibit low-efficiency levels.

\subsubsection{Advanced (Soft Computing) MPPT Methods}

Owing to the numerous drawbacks of the conventional MPPT methods, such as low efficiency and slow tracking speed under shading conditions [121], advanced methods were developed to address these issues. The advanced methods can reduce the perturbation level close to MPP. Being that the soft computing MPPT methods are more complex than the conventional techniques, they are mostly used for PSCs because of their reliability, robustness, and flexibility [122]. These techniques have demonstrated excellent performances in different applications under uniform and partial shading solar irradiance conditions. These techniques are mainly reliant on AI principles and other evolutionary algorithms (EA) [33]. As such, the genetic algorithm (GA), ANN, fuzzy logic controller (FLC) [123], and PSO are some of the most commonly applied advanced techniques [123-126]. The ability and flexibility of these algorithms in solving nonlinear tasks is their main strong point [127]; they can find the optimal solution or multipeak GMPPT with a reasonable level of high accuracy. Hence, they are considered superior to the conventional methods in terms of tracking performance.

\subsubsection{Hybrid MPPT Methods}

The hybrid methods are mostly used in solving the challenges of the singular methods because they can improve the overall efficiency and can perform well under partial shading conditions [128]. Hybrid MPPT methods have been proposed as the solution to the issues associated with conventional and advanced techniques. They are developed by combining different numbers of single techniques [129], such as the combination of soft computing algorithms with a conventional algorithm [130]; two soft computing-based algorithms can also be combined to form a hybrid system [131]. Hybrid techniques can achieve better tracking performance than singular algorithms. 


\section{Multilevel Converters in PV Systems}

The application of multilevel inverter (MLI) in PV systems to improve power quality and efficiency has received considerable interest recently. The selection of an appropriate converter for PV applications is one of the challenges since that has an impact on the behavior of the photovoltaic (PV) system. Therefore, many multilevel converters for the photovoltaic (PV) systems have been reported in the literature [113]. The study by [132] presented an MLC for PV systems with integrated ESS. The developed MLC can provide constant power irrespective of the weather conditions. The proposed MLC showed a smooth transition from the charging mode to the discharging mode. Hence, the cascaded $\mathrm{H}$-bridge $(\mathrm{CHB})$ converter can be used in grid interconnections owing to its modular attributes, high-quality output waveforms, and ability to connect to medium voltage grids. A CHB-MLC with DC-DC stage isolation has been presented by [133] for large-scale PV systems. The proposed CHB converter offered quality currents with low distortion. Its modular design ensured that it could operate in high voltage conditions and could improve the power quality. The study by [134] presented an improved CMLI with a reliable configuration for reduction of current leakages in transformerless PV systems; conduction and switching losses were also reduced, making high switching frequency operation possible.

The study by [135] presented a CHB converter for use in PV systems; the system utilized an H6-bridge power cell rather than the H-bridge type. The system significantly improved the current quality and output voltage in partial shading conditions compared to the CHB type; this improved the system efficiency and the energy injected into the grid. A modular MMC was used in grid-connected PV systems by [136]. The proposed system can perform in both active and reactive power conditions, and this extends the applicability of the PV systems. A hybrid modular MMC for grid-connected PV systems was presented by [137]; this system can be used in high power systems by simply increasing the number of submodules per phase.

\subsection{Multilevel Inverters for Grid-Connected PV Systems}

Different multilevel converter topologies have been investigated and compared in the literature $[138,139]$ to highlight the most suitable topology for PV applications that can operate under fundamental and high frequencies, deliver high-quality waveform with lower THD, achieve better electromagnetic compatibility, and exhibit high efficiency. In [140], a modified multilevel inverter topology was presented. This topology generates a seven-level voltage waveform with low harmonic contents. This inverter was confirmed suitable for use in photovoltaic applications for power delivery from PV panels of different voltage/current ratings to the grid. The study by [141] presented a new MLI configuration with fewer switches compared to the traditional MLI configuration; this configuration required no additional components, such as capacitors and inductors. It is a convenient configuration owing to its asymmetrical PV sources. It also exhibits fault-tolerant and modular capabilities. Owing to the greater number of sources, this structure offers higher voltage levels and provides a suitable sinusoidal voltage waveform. Being that this structure requires no filter, this inverter has a considerably low size and weight. A new basic asymmetrical MLI has been proposed by [142] for use in PV systems; this MLI was designed with a maximum number of components though the number of components required is still lower than in the classical MLI topologies. The system succeeded in generating 31 output levels and performed excellently under different load types. This topology also produces highly efficient AC output with low THD. Some of the recently proposed MLIs with a reduced number of components for use in grid integration have been comprehensively reviewed by [143] based on the selection of components, comparative factors, and their suitability. The design of a modular CHBMLI for use in single- or three-phase grid-connected applications has been presented by $[144,145]$. The idea behind this topology is to aid in improving the flexibility and efficiency of PV systems, ensure better PV module utilization, as well as to ensure maximum solar energy extraction. 
Performance analysis of the grid-connected photovoltaic system using two multilevel inverter topologies has been performed in [146]. The MPPT controller was implemented using a neural network algorithm to maximize the output power of the PV systems according to changes in the environmental conditions. The investigated inverter topologies performed excellently through the cascaded inverter and achieved lower current THD compared to the NPC topology. However, it is more expensive due to the number of power switching transistors it requires. The study by [147] presented a hybrid modular MLC (H-MMC) for the integration of solar power into the grid. With the connection of the PV-panels in each of the submodules of the converter, the proposed topology is suitable for high power use but requires that the number of submodules in each phase be increased. There are numerous advantages of hybrid-MMC compared to traditional MMC, such as lower capacitor count, higher voltage levels, higher efficiency, no circulating current, and less footprint. This converter was equipped with a global Maximum Power Point Tracking (MPPT) algorithm that requires only the current and voltage signals of just one submodule. The distributed nature of the MPPT addressed the drawbacks of global MPPT under partial shading. Table 2 is a comparison of the recent multilevel inverters for grid-connected PV systems in terms of inverter type, voltage levels, MPPT technique, number of used switches, and THD.

Table 2. A comparison of recent MLIs grid-connected PV systems in the literature.

\begin{tabular}{|c|c|c|c|c|c|}
\hline Ref. & Inverter Type & $\begin{array}{l}\text { Voltage } \\
\text { Level }\end{array}$ & MPPT & $\begin{array}{l}\text { No. of } \\
\text { Switches }\end{array}$ & THD \\
\hline [148] & $\begin{array}{l}\text { Nine-Level Active Neutral Point } \\
\text { Clamp Inverter }\end{array}$ & 9 & Predictive Control Technique & 10 & $13.99 \%$ \\
\hline [149] & Voltage Level Boost (VLB) MLI & 15 & $\begin{array}{c}\text { Distributed Maximum Power } \\
\text { Point Tracking (DMPPT) Control. }\end{array}$ & 10 & $5.54 \%$ \\
\hline [150] & $\begin{array}{l}\text { Neutral-Point-Clamped (NPC) } \\
\text { Multilevel Inverter }\end{array}$ & 4 & $\begin{array}{l}\text { Incremental Conductance } \\
\text { MPPT Algorithm }\end{array}$ & 11 & $4.61 \%$ \\
\hline [151] & Cascaded Multilevel Inverter (CHB) & 17 & Perturbation-Observation (P\&O) & & $3.23 \%$ \\
\hline [152] & $\begin{array}{l}\text { Neutral-Point-Clamped Multilevel } \\
\text { Inverter (NPC) }\end{array}$ & 5 & Artificial Neural Network (ANN) & 6 & $2.35 \%$ \\
\hline [152] & Cascaded Multilevel Inverter (CHB) & 5 & Artificial Neural Network (ANN) & 8 & $2.75 \%$ \\
\hline [135] & Cascaded Multilevel Inverter (CHB) & 7 & Perturb and Observe $(\mathrm{P} \& \mathrm{O})$ & $24(6 \mathrm{H})$ & $10.75 \%$ \\
\hline [153] & Cascaded Multilevel Inverter (CHB) & 5 & Perturb and Observe (P\&O) & 8 & $3.2 \%$ \\
\hline [154] & $\begin{array}{l}\text { Modular Cascaded H-Bridge Multilevel } \\
\text { inverter (MMC) }\end{array}$ & 7 & $\begin{array}{l}\text { Distributed MPPT } \\
\text { Control Scheme }\end{array}$ & 12 per phase & $4.2 \%$ \\
\hline [140] & Modified Cascaded Multilevel Inverter & 7 & Perturb and Observe $(\mathrm{P} \& \mathrm{O})$ & 6 & $3.1 \%$ \\
\hline [155] & Cascaded H-Bridge Multilevel inverter & 7 & $\begin{array}{l}\text { Distributed Maximum Point } \\
\text { Tracking (DMPPT) }\end{array}$ & 12 & $3.3 \%$ \\
\hline [156] & Modified Cascaded Multilevel Inverter & 7 & Perturb and Observe (P\&O) & 6 & $11.81 \%$ \\
\hline
\end{tabular}

\subsection{Common-Mode and Leakage Current Suppression for Transformerless ML PV Inverters}

Although the multilevel inverter (MLI) based grid-connected PV system is reliable in power generation, the galvanic connection is used between DC and bulk power AC transmission system using a high-frequency transformer. This affected the efficiency owing to the loss of more components; it also increased the cost. Therefore, the MLI topologies with no transformer are considered the best option for low cost, low THD, and highefficiency PV systems $[157,158]$. The obvious advantage of the transformerless topologies in grid-connected PV systems is that the issue of current leakage is eliminated; however, the technical challenge encountered is related to how to ensure a constant system commonmode voltage to minimize current leakage. However, the efficiency and reliability of the 
system are negatively affected due to the current leakage from the parasitic capacitance. It is, therefore, necessary that the problems associated with transformerless PV inverters be addressed carefully. Various techniques have been developed for tackling the issue of current leakage in transformerless string inverters; these techniques can be classified into 3 different groups as modulation solution [159,160], topology solution [161,162], and filter solution $[163,164]$. Current leakage can be significantly reduced by the bipolar modulation strategy through the maintenance of a constant common-mode voltage at the expense of the conversion efficiency and output current quality. Extra DC or AC switches are needed in the full-bridge topology to reduce current leakage [165,166]. Regarding the filter solution, it reduces current leakage through bypassing loops with low impedance for high-frequency common-mode noise; this prevents the outside flow of leakage current. An improved five-level CMLI has been proposed by [134] for the reduction of current leakage in transformerless PV system; the system was developed with low switch count and minimized leakage current through the elimination of the high-frequency transitions occurring at the CMVs and terminals. The conduction and switching losses were also reduced in the proposed system, making high switching frequency operation possible. A comprehensive analysis of the CMV and terminal voltage of PV-fed CHBMLIs has been presented in [167]. Two PWM schemes were proposed based on the concept of the redundant state for CHB nine-level MLI without increasing the number of elements in the circuit; the first scheme is to ensure low-frequency transitions in the terminal voltage to reduce the leakage current, while the second scheme is for the reduction of the commonmode current via maintenance of a constant CMV. The study by [168] presented a singlephase five-level transformerless inverter for PV systems; the study also presented the modulation strategy for this system. The leakage current is reduced in the proposed system by ensuring that the CMV is maintained at $50 \%$ of the DC-link voltage when outputting $\pm V d c / 2$ and zero voltage levels. Hence, both leakage current and high-frequent CMV are suppressed. In [169], a modified common-mode MCM-filter configuration was used to address the issue of spurious load trips, as well as to minimize the ground leakage current adequately in the system; the system is also applicable in three-phase applications.

\section{Challenges and Future Work Areas}

Renewable energy systems have gained more application in the power grid due to the advancements in power electronics devices and related technologies. However, this has generated many concerns in terms of the power quality, protection, energy storage, the intermittent nature of the energy fed to the grid, and system reliability. Hence, several standards and codes have been developed for grid interfaced RESs to ensure the power quality at the grid is maintained [42,170]. In view of the reviewed literature, there are areas in this regard that demand more studies; these are highlighted as follows:

- The intermittent nature of the produced power by RESs remains one of the major issues in grid-connected RES. It is believed that the contribution of RESs to the global energy market will increase in the future; hence, this problem of power fluctuations in grid-connected RESs demands to be addressed.

- Multilevel inverters (MLIs) have been widely used in both grid-connected and industrial applications over time owing to their numerous advantages. However, researchers have recently begun to introduce hybrid topologies which are developed from the classical topologies; these hybrid methods are developed to meet the high grid code standards and address the power quality problems in a cost-friendly manner $[16,23,58]$. Being that most of these new topologies have not been evaluated in the grid-connected RESs, there is a need to investigate their performance in gridintegrated applications.

- The MMC, a commonly used MC, remains the most suitable for large-scale RES application. MMC has become the basic building block for multiterminal direct current (MTDC) and DC grids due to its salient features, The MMCMTDC systems embedded into the present power system will significantly enhance system reliability 
and efficiency, support renewable energy integration, and improve the economy and flexibility of power transmission. However, there are still several technical challenges in the modeling, control, and protection of the MMC-MTDC systems [171-174].

- More studies are needed on the performance analysis of the recent MLIs to efficiently address the issues encountered in the grid-connected RESs applications. Studies should also focus on the role of MLIs in smart grid technologies.

- Even though the Reduced Switch Multilevel Inverter (RS MLI) topologies can be used in RES integration, especially for PV applications, in consideration of the reduced total standing voltage (TSV), more RS MLI topologies should be developed to increase the suitability for the integration of both PV and wind energy systems [88].

- The integration of renewable energy systems to grids using suitable MLIs has gradually been moving grid systems towards the future smart grid. This comes with great challenges but also presents some opportunities for MLI topology development and control. Thus, there are numerous innovations in this field.

- The regulation of DC-link voltage, as well as the control of the MPPT in MLIs, usually requires a PI-based controller which is associated with certain limitations. Several soft computing and hybrid methods-based control systems can be evaluated for better multidimensional control [42].

- The efficiency of the MPPT algorithm is affected by many factors but the most obvious is the nonlinear nature of the PV system, the system working condition, and the variations in ambient conditions. Most times, the algorithm developers do not consider these changes, and this has been the source of system failure in certain working conditions. Thus, the design of the PV module controller is a tedious task that demands more attention to achieve stability [31,116].

- A key determinant of the proper MPPT to be selected is to find the optimal MPPT method with fast performance, low tracking errors, and no oscillation around the GMMP. The evaluation of MPPT techniques normally comes with various degrees of complexity; hence, many studies are still ongoing, trying to address most of the identified problems. It is, therefore, recommended that efforts should be geared towards finding a simpler, faster, and cost-efficient MPP tracker that could offer better reliability and efficiency [31,175].

\section{Conclusions}

This paper has briefly outlined the aspects of multilevel inverters to highlight the need for further investigation. This paper has briefly outlined the aspects of multilevel inverters to highlight the need to produce new inverters or modified combinations of inverters for grid-connected and PV systems. MLIs have been elaborated in various aspects, such as classifications, advantages, disadvantages, and their abilities to enhance energy conversion in modern energy systems. Based on this review, a modified approach using MLIs for different levels should employ standard MLIs to reduce the switching count. Modified MLIs are promising solutions for PV and other renewable energy systems in terms of size, cost, less THD, and high efficiency energy conversion. Besides, the most recent MLIs grid-connected PV systems, and the minimizing current leakage suppression methods were highlighted in this work. Lastly, the challenges and practical recommendations for developing an efficient system were highlighted to motivate and guide society to focus on inventing an efficient and economic MLIs grid-connected system that combines most of the used and reported inverters' capabilities.

Author Contributions: Conceptualization, A.B., M.S. and A.R.; methodology, S.A. and D.I.; writingoriginal draft preparation, A.B., M.S. and S.A.; investigation, D.I., M.S. and A.R.; resources, S.A. and A.B.; writing-review and editing, M.S., A.R. and D.I.; visualization, M.S. and A.R.; supervision, M.S. and D.I; funding acquisition, A.R., M.S. and A.B. All authors have read and agreed to the published version of the manuscript. 
Funding: This work was supported in part by Universiti Sains Malaysia, under short-term grant No. 304/PELECT/6315330.

Institutional Review Board Statement: Not applicable.

Data Availability Statement: Not applicable.

Conflicts of Interest: The authors declare no conflict of interest.

\begin{tabular}{ll} 
Abbreviations \\
MLI & Multilevel Inverter \\
PV & Photovoltaic \\
MPPT & Maximum Power Point Tracking \\
RESs & Renewable Energy Sources \\
THD & Total Harmonic Distortion \\
EMI & Electro-Magnetic Interference \\
MMPP & Multiple Maximum Power Points \\
GMPP & Global Maximum Power Point \\
PWM & Pulse Width Modulation \\
CHB-MLI & Cascaded H-Bridge Multilevel Inverter \\
DCMLI & Diode Clamped Multilevel Inverter \\
FCMLI & Flying Capacitor Multilevel Inverter \\
SDCS & Separate DC Source \\
SWAs & Split-Winding Alternators \\
MMC & Modular Multilevel Converter \\
PCC & Point of Common Coupling \\
CSD & Cascaded Switched-Diode \\
BESS & Battery Energy Storage System \\
SOC & State of Charge \\
MCSI & Multilevel Current-Source Inverter \\
PPP & Peak Power Point \\
TSV & Total Standing Voltage \\
VFISPWM & Variable Frequency Inverted Sine Carrier PWM \\
Iph & Photon-Generated Current \\
& \\
\hline
\end{tabular}

\section{References}

1. Nema, P.; Nema, R.; Rangnekar, S. A current and future state of art development of hybrid energy system using wind and PV-solar: A review. Renew. Sustain. Energy Rev. 2009, 13, 2096-2103. [CrossRef]

2. Haque, A. Research on Solar Photovoltaic (PV) Energy Conversion System: An Overview. In Proceedings of the Third International Conference on Computational Intelligence and Information Technology (CIIT 2013), Mumbai, India, 18-19 October 2013; pp. 605-611.

3. Solanki, C.S. Solar Photovoltaics: Fundamentals, Technologies and Applications, 3rd ed.; PHI Learning Pvt. Ltd.: Delhi, India, 2015.

4. IEA International Energy Agency. World Energy Outlook; OECD: Paris, France, 2004.

5. Panwar, N.; Kaushik, S.; Kothari, S. Role of renewable energy sources in environmental protection: A review. Renew. Sustain. Energy Rev. 2011, 15, 1513-1524. [CrossRef]

6. Alhafadhi, L.; Teh, J.; Lai, C.M.; Salem, M. Predictive Adaptive Filter for Reducing Total Harmonics Distortion in PV Systems. Energies 2020, 13, 3286. [CrossRef]

7. Ibrahim, A.; Fudholi, A.; Sopian, K.; Othman, M.Y.; Ruslan, M.H. Efficiencies and improvement potential of building integrated photovoltaic thermal (BIPVT) system. Energy Convers. Manag. 2014, 77, 527-534. [CrossRef]

8. Bosshard, P.; Hermann, W.; Hung, E.; Hunt, R.; Simon, A. An assessment of solar energy conversion technologies and research opportunities. Gcep Energy Assess. Anal. 2006, 45.

9. Peumans, P.; Forrest, S. Very-high-efficiency double-heterostructure copper phthalocyanine/C 60 photovoltaic cells. Appl. Phys. Lett. 2001, 79, 126-128. [CrossRef]

10. Masuko, K.; Shigematsu, M.; Hashiguchi, T.; Fujishima, D.; Kai, M.; Yoshimura, N.; Yamaguchi, T.; Ichihashi, Y.; Mishima, T.; Matsubara, N.; et al. Achievement of More Than 25\% Conversion Efficiency With Crystalline Silicon Heterojunction Solar Cell. IEEE J. Photovolt. 2014, 4, 1433-1435. [CrossRef]

11. Mitzi, D.B.; Yuan, M.; Liu, W.; Kellock, A.J.; Chey, S.J.; Deline, V.; Schrott, A.G. A high-efficiency solution-deposited thin-film photovoltaic device. Adv. Mater. 2008, 20, 3657-3662. [CrossRef]

12. Kouro, S.; Leon, J.I.; Vinnikov, D.; Franquelo, L.G. Grid-connected photovoltaic systems: An overview of recent research and emerging PV converter technology. IEEE Ind. Electron. Mag. 2015, 9, 47-61. [CrossRef] 
13. Hassaine, L.; OLias, E.; Quintero, J.; Salas, V. Overview of power inverter topologies and control structures for grid connected photovoltaic systems. Renew. Sustain. Energy Rev. 2014, 30, 796-807. [CrossRef]

14. Monfared, M.; Golestan, S. Control strategies for single-phase grid integration of small-scale renewable energy sources: A review. Renew. Sustain. Energy Rev. 2012, 16, 4982-4993. [CrossRef]

15. Daher, S.; Schmid, J.; Antunes, F.L. Multilevel inverter topologies for stand-alone PV systems. IEEE Trans. Ind. Electron. 2008, 55, 2703-2712. [CrossRef]

16. Omer, P.; Kumar, J.; Surjan, B.S. A Review on Reduced Switch Count Multilevel Inverter Topologies. IEEE Access 2020, 8 , 22281-22302. [CrossRef]

17. Baker, R.H.; Bannister, L.H. Electric Power Converter. U.S. Patent 386,743A, 18 February 1975.

18. Nabae, A.; Takahashi, I.; Akagi, H. A new neutral-point-clamped PWM inverter. IEEE Trans. Ind. Appl. 1981, 5, 518-523. [CrossRef]

19. Aiello, M.F.; Hammond, P.W.; Rastogi, M. Modular Multi-Level Adjustable Supply with Series Connected Active Inputs. U.S. Patent 6,236,580B1, 22 May 2001.

20. Peng, F.; Lai, J.-S. Multilevel Cascade Voltage Source Inverter with Separate Dc Sources. U.S. Patent 5,642,275A, 24 June 1997.

21. Abd Halim, W.; Ganeson, S.; Azri, M.; Azam, T.T. Review of multilevel inverter topologies and its applications. J. Telecommun. Electron. Comput. Eng. 2016, 8, 51-56.

22. Tolbert, L.M.; Shi, X. Multilevel power converters. In Power Electronics Handbook; Elsevier: Amsterdam, The Netherlands, 2018; pp. 385-416.

23. Prabaharan, N.; Palanisamy, K. A comprehensive review on reduced switch multilevel inverter topologies, modulation techniques and applications. Renew. Sustain. Energy Rev. 2017, 76, 1248-1282. [CrossRef]

24. Danandeh, M. Comparative and comprehensive review of maximum power point tracking methods for PV cells. Renew. Sustain. Energy Rev. 2018, 82, 2743-2767. [CrossRef]

25. Motahhir, S.; El Ghzizal, A.; Sebti, S.; Derouich, A. Shading effect to energy withdrawn from the photovoltaic panel and implementation of DMPPT using C language. Int. Rev. Autom. Control 2016, 9, 88-94. [CrossRef]

26. Wang, Y.; Li, Y.; Ruan, X. High-accuracy and fast-speed MPPT methods for PV string under partially shaded conditions. IEEE Trans. Ind. Electron. 2015, 63, 235-245. [CrossRef]

27. Belhachat, F.; Larbes, C. A review of global maximum power point tracking techniques of photovoltaic system under partial shading conditions. Renew. Sustain. Energy Rev. 2018, 92, 513-553. [CrossRef]

28. Sivachandran, P.; Lakshmi, D.; Janani, R. Survey of maximum power point tracking techniques in solar PV system under partial shading conditions. ARPN J. Eng. Appl. Sci. 2015, 10, 256-264.

29. Karami, N.; Moubayed, N.; Outbib, R. General review and classification of different MPPT Techniques. Renew. Sustain. Energy Rev. 2017, 68, 1-18. [CrossRef]

30. Subudhi, B.; Pradhan, R. A Comparative Study on Maximum Power Point Tracking Techniques for Photovoltaic Power Systems. IEEE Trans. Sustain. Energy 2013, 4, 89-98. [CrossRef]

31. Baba, A.O.; Liu, G.; Chen, X. Classification and Evaluation Review of Maximum Power Point Tracking Methods. Sustain. Futures 2020, 2, 100020. [CrossRef]

32. Salam, Z.; Ahmed, J.; Merugu, B.S. The application of soft computing methods for MPPT of PV system: A technological and status review. Appl. Energy 2013, 107, 135-148. [CrossRef]

33. Çelik, Ö.; Teke, A. A Hybrid MPPT method for grid connected photovoltaic systems under rapidly changing atmospheric conditions. Electr. Power Syst. Res. 2017, 152, 194-210. [CrossRef]

34. Rodriguez, J.; Lai, J.-S.; Peng, F.Z. Multilevel inverters: A survey of topologies, controls, and applications. IEEE Trans. Ind. Electron. 2002, 49, 724-738. [CrossRef]

35. Pharne, I.; Bhosale, Y. A Review on Multilevel Inverter Topology. In Proceedings of the 2013 International Conference on Power, Energy and Control (ICPEC), Dindigul, India, 6-8 February 2013; pp. 700-703.

36. Rodríguez, J.; Bernet, S.; Wu, B.; Pontt, J.O.; Kouro, S. Multilevel voltage-source-converter topologies for industrial mediumvoltage drives. IEEE Trans. Ind. Electron. 2007, 54, 2930-2945. [CrossRef]

37. Rodriguez, J.; Franquelo, L.G.; Kouro, S.; Leon, J.I.; Portillo, R.C.; Prats, M.A.M.; Perez, M.A. Multilevel converters: An enabling technology for high-power applications. Proc. IEEE 2009, 97, 1786-1817. [CrossRef]

38. Kouro, S.; Malinowski, M.; Gopakumar, K.; Pou, J.; Franquelo, L.G.; Wu, B.; Rodriguez, J.; Pérez, M.A.; Leon, J.I. Recent advances and industrial applications of multilevel converters. IEEE Trans. Ind. Electron. 2010, 57, 2553-2580. [CrossRef]

39. Sira-Ramirez, H.J.; Silva-Ortigoza, R. Control Design Techniques in Power Electronics Devices; Springer Science \& Business Media: Berlin/Heidelberg, Germany, 2006.

40. Murugesan, M.; Pari, R.; Sivakumar, R.; Sivaranjani, S. Different types of multilevel inverter topologies-A technical Review. Int. J. Adv. Engg. Tech. 2016, 7, 155.

41. Hasan, N.S.; Rosmin, N.; Osman, D.A.A.; Musta'amal, A.H. Reviews on multilevel converter and modulation techniques. Renew. Sustain. Energy Rev. 2017, 80, 163-174. [CrossRef]

42. Kala, P.; Arora, S. A comprehensive study of classical and hybrid multilevel inverter topologies for renewable energy applications. Renew. Sustain. Energy Rev. 2017, 76, 905-931. [CrossRef]

43. Shehu, G.S.; Kunya, A.B.; Shanono, I.H.; Yalçınöz, T. A review of multilevel inverter topology and control techniques. J. Autom. Control Eng. 2016, 4. [CrossRef] 
44. Peng, F.; McKeever, J.; Adams, D. Cascade multilevel inverters for utility applications. In Proceedings of the IECON'97 23rd International Conference on Industrial Electronics, Control, and Instrumentation (Cat. No. 97CH36066), New Orleans, LA, USA, 14 November 1997; pp. 437-442. [CrossRef]

45. Escalante, M.F.; Vannier, J.-C.; Arzandé, A. Flying capacitor multilevel inverters and DTC motor drive applications. IEEE Trans. Ind. Electron. 2002, 49, 809-815. [CrossRef]

46. Yuan, X.; Barbi, I. Fundamentals of a new diode clamping multilevel inverter. IEEE Trans. Power Electron. 2000, 15, 711-718. [CrossRef]

47. Sumithira, T.; Nirmal Kumar, A. Elimination of harmonics in multilevel inverters connected to solar photovoltaic systems using ANFIS: An experimental case study. J. Appl. Res. Technol. 2013, 11, 124-132. [CrossRef]

48. Hassan, A.; Yang, X.; Chen, W.; Houran, M.A. A State of the Art of the Multilevel Inverters with Reduced Count Components. Electronics 2020, 9, 1924. [CrossRef]

49. Rivera, S.; Kouro, S.; Wu, B.; Leon, J.I.; Rodríguez, J.; Franquelo, L. Cascaded H-Bridge Multilevel Converter Multistring Topology for Large Scale Photovoltaic Systems. In Proceedings of the 2011 IEEE International Symposium on Industrial Electronics, Gdansk, Poland, 27-30 June 2011; pp. 1837-1844.

50. Saeedian, M.; Adabi, J.; Hosseini, S.M. Cascaded multilevel inverter based on symmetric-asymmetric DC sources with reduced number of components. IET Power Electron. 2017, 10, 1468-1478. [CrossRef]

51. Tolbert, L.M.; Peng, F.Z.; Habetler, T.G. Multilevel inverters for electric vehicle applications. In Proceedings of the Power Electronics in Transportation (Cat. No. 98TH8349), Gdansk, Poland, 27-30 June 2011; pp. 79-84.

52. Panda, A.K.; Suresh, Y. Research on cascade multilevel inverter with single DC source by using three-phase transformers. Int. J. Electr. Power Energy Syst. 2012, 40, 9-20. [CrossRef]

53. Meynard, T.; Foch, H. Multi-level conversion: High voltage choppers and voltage-source inverters. In Proceedings of the PESC'92 Record. 23rd Annual IEEE Power Electronics Specialists Conference, Toledo, Spain, 29 June-3 July 1992; pp. $397-403$.

54. Chen, A.; He, X. Research on hybrid-clamped multilevel-inverter topologies. IEEE Trans. Ind. Electron. 2006, 53, 1898-1907. [CrossRef]

55. Rodriguez, J.; Bernet, S.; Steimer, P.K.; Lizama, I.E. A Survey on Neutral-Point-Clamped Inverters. IEEE Trans. Ind. Electron. 2010, 57, 2219-2230. [CrossRef]

56. El-Hosainy, A.; Hamed, H.A.; Azazi, H.Z.; El-Kholy, E. A review of multilevel inverter topologies, control techniques, and applications. In Proceedings of the 2017 Nineteenth International Middle East Power Systems Conference (MEPCON), Cairo, Egypt, 19-21 December 2017; pp. 1265-1275.

57. Balamurugan, C.; Natarajan, S.; Arumugam, M. A review on various multilevel inverter topologies. Glob. J. Adv. Res. 2015, 2, 11.

58. Vijeh, M.; Rezanejad, M.; Samadaei, E.; Bertilsson, K. A general review of multilevel inverters based on main submodules: Structural point of view. IEEE Trans. Power Electron. 2019, 34, 9479-9502. [CrossRef]

59. Krishna, R.A.; Suresh, L.P. A brief review on multi level inverter topologies. In Proceedings of the 2016 International Conference on Circuit, Power and Computing Technologies (ICCPCT), Nagercoil, India, 18-19 March 2016; pp. 1-6.

60. Kieferndorf, F.; Basler, M.; Serpa, L.; Fabian, J.-H.; Coccia, A.; Scheuer, G. A new medium voltage drive system based on ANPC-5L technology. In Proceedings of the 2010 IEEE International Conference on Industrial Technology, Via del Mar, Chile, 14-17 March 2010; pp. 643-649.

61. Subarnan, J.G. Multilevel inverters: An enabling technology. In Hybrid-Renewable Energy Systems in Microgrids; Elsevier: Amsterdam, The Netherlands, 2018; pp. 61-80.

62. McGrath, B.P.; Holmes, D.G. Analytical Modelling of Voltage Balance Dynamics for a Flying Capacitor Multilevel Converter. IEEE Trans. Power Electron. 2008, 23, 543-550. [CrossRef]

63. Suneel, T. Multi Level Inverters: A Review Report. Int. J. New Technol. Sci. Eng. 2014, 1, 82-109.

64. Deepak, P.C.; Rao, S.N. Cascaded H-Bridge Multilevel Inverter Using Inverted Sine Wave PWM Technique. Int. J. Emerg. Trends Electr. Electron. 2013, 6, 39-44.

65. Malinowski, M.; Gopakumar, K.; Rodriguez, J.; Pérez, M.A. A Survey on Cascaded Multilevel Inverters. IEEE Trans. Ind. Electron. 2010, 57, 2197-2206. [CrossRef]

66. Venkataramanaiah, J.; Suresh, Y.; Panda, A.K. A review on symmetric, asymmetric, hybrid and single DC sources based multilevel inverter topologies. Renew. Sustain. Energy Rev. 2017, 76, 788-812. [CrossRef]

67. Masoudina, F.; Babaei, E.; Sabahi, M.; Alipour, H. New Cascaded Multilevel Inverter With Reduced Power Electronic Components. Iran. J. Electr. Electron. Eng. 2020, 16, 107-113.

68. Lee, J.; Sim, H.; Kim, J.; Lee, K. Combination Analysis and Switching Method of a Cascaded H-Bridge Multilevel Inverter Based on Transformers With the Different Turns Ratio for Increasing the Voltage Level. IEEE Trans. Ind. Electron. 2018, 65, 4454-4465. [CrossRef]

69. KJ, P.; Jagadanand, G.; Ramchand, R. A generalized space vector modulation scheme based on a switch matrix for cascaded H-bridge multilevel inverters. J. Power Electron. 2018, 18, 522-532.

70. Prabaharan, N.; Palanisamy, K. Modeling and analysis of a quasi-linear multilevel inverter for photovoltaic application. Energy Procedia 2016, 103, 256-261. [CrossRef]

71. Prabaharan, N.; Palanisamy, K. Analysis of cascaded H-bridge multilevel inverter configuration with double level circuit. IET Power Electron. 2017, 10, 1023-1033. [CrossRef] 
72. Shuvo, S.; Hossain, E.; Islam, T.; Akib, A.; Padmanaban, S.; Khan, M.Z.R. Design and hardware implementation considerations of modified multilevel cascaded H-bridge inverter for photovoltaic system. IEEE Access 2019, 7, 16504-16524. [CrossRef]

73. Kangarlu, M.F.; Babaei, E. Cross-switched multilevel inverter: An innovative topology. IET Power Electron. $2013,6,642-651$. [CrossRef]

74. Pozzebon, G.G.; Machado, R.Q.; Buso, S.; Spiazzi, G. A grid-connected multilevel converter for interfacing PV arrays and energy storage devices. In Proceedings of the IECON 2013-39th Annual Conference of the IEEE Industrial Electronics Society, Vienna, Austria, 10-14 November 2013; pp. 6158-6163.

75. Buticchi, G.; Lorenzani, E.; Franceschini, G. A five-level single-phase grid-connected converter for renewable distributed systems. IEEE Trans. Ind. Electron. 2012, 60, 906-918. [CrossRef]

76. Balikci, A.; Akpinar, E. A multilevel converter with reduced number of switches in STATCOM for load balancing. Electr. Power Syst. Res. 2015, 123, 164-173. [CrossRef]

77. Lezana, P.; Rodríguez, J.; Oyarzún, D.A. Cascaded multilevel inverter with regeneration capability and reduced number of switches. IEEE Trans. Ind. Electron. 2008, 55, 1059-1066. [CrossRef]

78. Babaei, E.; Hosseini, S.H. New cascaded multilevel inverter topology with minimum number of switches. Energy Convers. Manag. 2009, 50, 2761-2767. [CrossRef]

79. Prabaharan, N.; Palanisamy, K. Comparative analysis of symmetric and asymmetric reduced switch MLI topologies using unipolar pulse width modulation strategies. IET Power Electron. 2016, 9, 2808-2823. [CrossRef]

80. Natarajan, P.; Palanisamy, K. Investigation of single phase reduced switch count asymmetric multilevel inverter using advanced pulse width modulation technique. Int. J. Renew. Energy Res. 2015, 5, 879-890.

81. Prabaharan, N.; Arun, V.; Chinnadurai, T.; Arulkumar, K.; Jerin, A.R.A.; Palanisamy, K. Analysis of symmetric multilevel inverter using unipolar pulse width modulation for photovoltaic application. Comptes Rendus De L'academie Bulg. Des Sci. 2018, 71, 252-260.

82. Bassi, H.M.; Salam, Z. A new hybrid multilevel inverter topology with reduced switch count and dc voltage sources. Energies 2019, 12, 977. [CrossRef]

83. Prabaharan, N.; Palanisamy, K. A new hybrid asymmetric multilevel inverter with reduced number of switches. In Proceedings of the 2016 IEEE International Conference on Power Electronics, Drives and Energy Systems (PEDES), Trivandrum, India, 14-17 December 2016; pp. 1-4.

84. Hinago, Y.K.; Hirotaka, K. A single-phase multilevel inverter using switched series/parallel dc voltage sources. IEEE Trans. Ind. Electron. 2010, 57, 2643-2650. [CrossRef]

85. Prabaharan, N.; Palanisamy, K. A single phase grid connected hybrid multilevel inverter for interfacing photo-voltaic system. Energy Procedia 2016, 103, 250-255. [CrossRef]

86. Prabaharan, N.; Saravanan, S.; Jerin, A.R.A.; Palanisamy, K. A Reduced Switch Asymmetric Multilevel Inverter Topology Using Unipolar Pulse Width Modulation Strategies for Photovoltaic Application. In Recent Developments on Power Inverters; Intechopen: London, UK, 2017; pp. 29-48.

87. Gupta, K.K.; Jain, S. A novel multilevel inverter based on switched DC sources. IEEE Trans. Ind. Electron. 2014, 61, 3269-3278. [CrossRef]

88. Alatai, S.; Salem, M.; Ishak, D.; Kamarol, M.; Jamil, M.; Bughneda, A. Design and Analysis of Five-level cascaded LLC Resonant Converter. In Proceedings of the 2020 IEEE International Conference on Power and Energy (PECon), Penang, Malaysia, 7-8 December 2020; pp. 66-70.

89. Mahalakshmi, R.; Thampatty, K.S. Grid connected multilevel inverter for renewable energy applications. Procedia Technol. 2015, 21, 636-642. [CrossRef]

90. Samuel, P.; Gupta, R.; Chandra, D. Grid interface of wind power with large split-winding alternator using cascaded multilevel inverter. IEEE Trans. Energy Convers. 2011, 26, 299-309. [CrossRef]

91. Debnath, S.; Saeedifard, M. A new hybrid modular multilevel converter for grid connection of large wind turbines. IEEE Trans. Sustain. Energy 2013, 4, 1051-1064. [CrossRef]

92. Wang, L.; Wu, Q.; Tang, W. Novel cascaded switched-diode multilevel inverter for renewable energy integration. IEEE Trans. Energy Convers. 2017, 32, 1574-1582. [CrossRef]

93. Parker, M.A.; Ran, L.; Finney, S.J. Distributed Control of a Fault-Tolerant Modular Multilevel Inverter for Direct-Drive Wind Turbine Grid Interfacing. IEEE Trans. Ind. Electron. 2013, 60, 509-522. [CrossRef]

94. Seyezhai, R.; Mathur, B. Hybrid multilevel inverter using ISPWM technique for fuel cell applications. Int. J. Comput. Appl. 2010, 9 , 41-47. [CrossRef]

95. Rahul, J.R.; Kirubakaran, A.; Vijayakumar, D. A new multilevel DC-DC boost converter for fuel cell based power system. In Proceedings of the 2012 IEEE Students' Conference on Electrical, Electronics and Computer Science, Bhopal, India, 1-2 March 2012; pp. 1-5.

96. Seyezhai, R.; Mathur, B. Hybrid cascaded H-bridge multilevel inverter for fuel cell power conditioning systems. In Proceedings of the 2008 43rd International Universities Power Engineering Conference, Padua, Italy, 1-4 September 2008; pp. 1-5.

97. Singh, R.; Nakka, J. Design, simulation and performance analysis of Fuel Cell based energy system with Cascaded H-Bridge Multilevel Inverter. In Proceedings of the 2016 IEEE 1st International Conference on Power Electronics, Intelligent Control and Energy Systems (ICPEICES), Delhi, India, 4-6 July 2016; pp. 1-6. 
98. Kumar, L.S.; Teja, O.S. Harmonic analysis of diode clamped multilevel inverter base PEM fuel cell energy system. In Proceedings of the 2017 International Conference on Energy, Communication, Data Analytics and Soft Computing (ICECDS), Chennai, India, 1-2 August 2017; pp. 2801-2806.

99. Cossutta, P.; Aguirre, M.P.; Cao, A.; Raffo, S.; Valla, M.I. Single-stage fuel cell to grid interface with multilevel current-source inverters. IEEE Trans. Ind. Electron. 2015, 62, 5256-5264. [CrossRef]

100. Maharjan, L.; Yamagishi, T.; Akagi, H.; Asakura, J. Fault-tolerant operation of a battery-energy-storage system based on a multilevel cascade PWM converter with star configuration. IEEE Trans. Power Electron. 2010, 25, 2386-2396. [CrossRef]

101. Maharjan, L.; Yamagishi, T.; Akagi, H. Active-Power Control of Individual Converter Cells for a Battery Energy Storage System Based on a Multilevel Cascade PWM Converter. IEEE Trans. Power Electron. 2012, 27, 1099-1107. [CrossRef]

102. Zheng, Z.; Wang, K.; Xu, L.; Li, Y. A Hybrid Cascaded Multilevel Converter for Battery Energy Management Applied in Electric Vehicles. IEEE Trans. Power Electron. 2014, 29, 3537-3546. [CrossRef]

103. Quraan, M.; Yeo, T.; Tricoli, P. Design and Control of Modular Multilevel Converters for Battery Electric Vehicles. IEEE Trans. Power Electron. 2016, 31, 507-517. [CrossRef]

104. Quraan, M.; Tricoli, P.; D'Arco, S.; Piegari, L. Efficiency Assessment of Modular Multilevel Converters for Battery Electric Vehicles. IEEE Trans. Power Electron. 2017, 32, 2041-2051. [CrossRef]

105. Gadalla, A.S.; Yan, X.; Hasabelrasul, H. Performance of the battery energy storage systems based on cascaded H-bridge multilevel converter. J. Eng. 2019, 2019, 779-783. [CrossRef]

106. Gao, Z.; Lu, Q. A Hybrid Cascaded Multilevel Converter Based on Three-Level Cells for Battery Energy Management Applied in Electric Vehicles. IEEE Trans. Power Electron. 2019, 34, 7326-7349. [CrossRef]

107. Diong, B.; Basireddy, S.; Corzine, K.; Familiant, Y. Multilevel inverters with equal or unequal sources for dual-frequency induction heating. In Proceedings of the Nineteenth Annual IEEE Applied Power Electronics Conference and Exposition, Anaheim, CA, USA, 22-26 February 2004; pp. 825-831.

108. Qingfeng, L.; Huamin, W.; Zhaoxia, L. Discuss on the application of multilevel inverter in high frequency induction heating power supply. In Proceedings of the TENCON 2006-2006 IEEE Region 10 Conference, Hong Kong, China, 14-17 November 2006; pp. 1-4.

109. Flayyih, B.M.; Ahmed, M.Z.; Ambroze, M. A novel hybrid votage-current fed induction heating power supply system using multilevel neutral point clamped inverter. In Proceedings of the 2014 IEEE International Energy Conference (ENERGYCON), Cavtat, Croatia, 13-16 May 2014; pp. 189-194.

110. Flayyih, B.M.; Ahmed, M.Z.; Ambroze, M. An Optimum Harmonic Control of induction heating power supply system using multilevel neutral point clamped inverter. In Proceedings of the 2016 IEEE Transportation Electrification Conference and Expo, Asia-Pacific (ITEC Asia-Pacific), Busan, Korea, 1-4 June 2016; pp. 531-536.

111. Yue, Y.; Xu, Q.; Luo, A.; Guo, P.; He, Z.; Li, Y. Analysis and control of tundish induction heating power supply using modular multilevel converter. IET Gener. Transm. Distrib. 2018, 12, 3452-3460. [CrossRef]

112. Flayyih, B.M.; Ahmed, M.Z.; MacVeigh, S. A comprehensive power analysis of induction heating power supply system using multilevel neutral point clamped inverter with optimum control algorithm. In Proceedings of the 2015 IEEE 11th International Conference on Power Electronics and Drive Systems, Sydney, NSW, Australia, 9-12 June 2015; pp. 727-731.

113. Gopi, R.R.; Sreejith, S. Converter topologies in photovoltaic applications-A review. Renew. Sustain. Energy Rev. 2018, 94, 1-14. [CrossRef]

114. Bhatnagar, P.; Nema, R. Maximum power point tracking control techniques: State-of-the-art in photovoltaic applications. Renew. Sustain. Energy Rev. 2013, 23, 224-241. [CrossRef]

115. Kamarzaman, N.A.; Tan, C.W. A comprehensive review of maximum power point tracking algorithms for photovoltaic systems. Renew. Sustain. Energy Rev. 2014, 37, 585-598. [CrossRef]

116. Ahmad, R.; Murtaza, A.F.; Sher, H.A. Power tracking techniques for efficient operation of photovoltaic array in solar applicationsA review. Renew. Sustain. Energy Rev. 2019, 101, 82-102. [CrossRef]

117. Femia, N.; Petrone, G.; Spagnuolo, G.; Vitelli, M. A technique for improving P\&O MPPT performances of double-stage gridconnected photovoltaic systems. IEEE Trans. Ind. Electron. 2009, 56, 4473-4482.

118. Brambilla, A.; Gambarara, M.; Garutti, A.; Ronchi, F. New approach to photovoltaic arrays maximum power point tracking. In Proceedings of the 30th Annual IEEE Power Electronics Specialists Conference. Record.(Cat. No. 99CH36321), Charleston, SC, USA, 1 July 1999; pp. 632-637.

119. Elgendy, M.A.; Zahawi, B.; Atkinson, D.J. Assessment of the incremental conductance maximum power point tracking algorithm. IEEE Trans. Sustain. Energy 2012, 4, 108-117. [CrossRef]

120. Xiao, W.; Dunford, W.G. A modified adaptive hill climbing MPPT method for photovoltaic power systems. In Proceedings of the 2004 IEEE 35th Annual Power Electronics Specialists Conference (IEEE Cat. No. 04CH37551), Aachen, Germany, 20-25 June 2004; pp. 1957-1963.

121. Miyatake, M.; Veerachary, M.; Toriumi, F.; Fujii, N.; Ko, H. Maximum power point tracking of multiple photovoltaic arrays: A PSO approach. IEEE Trans. Aerosp. Electron. Syst. 2011, 47, 367-380. [CrossRef]

122. Ahmed, J.; Salam, Z. A critical evaluation on maximum power point tracking methods for partial shading in PV systems. Renew. Sustain. Energy Rev. 2015, 47, 933-953. [CrossRef]

123. Dounis, A.I.; Kofinas, P.; Alafodimos, C.; Tseles, D. Adaptive fuzzy gain scheduling PID controller for maximum power point tracking of photovoltaic system. Renew. Energy 2013, 60, 202-214. [CrossRef] 
124. Messalti, S.; Harrag, A.; Loukriz, A. A new variable step size neural networks MPPT controller: Review, simulation and hardware implementation. Renew. Sustain. Energy Rev. 2017, 68, 221-233. [CrossRef]

125. Hadji, S.; Gaubert, J.-P.; Krim, F. Theoretical and experimental analysis of genetic algorithms based MPPT for PV systems. Energy Procedia 2015, 74, 772-787. [CrossRef]

126. Liu, Y.-H.; Huang, S.-C.; Huang, J.-W.; Liang, W.-C. A particle swarm optimization-based maximum power point tracking algorithm for PV systems operating under partially shaded conditions. IEEE Trans. Energy Convers. 2012, 27, 1027-1035. [CrossRef]

127. Ishaque, K.; Salam, Z.; Taheri, H.; Shamsudin, A. A critical evaluation of EA computational methods for Photovoltaic cell parameter extraction based on two diode model. Sol. Energy 2011, 85, 1768-1779. [CrossRef]

128. Lian, K.; Jhang, J.; Tian, I. A maximum power point tracking method based on perturb-and-observe combined with particle swarm optimization. IEEE J. Photovolt. 2014, 4, 626-633. [CrossRef]

129. Yüksek, G.; Mete, A.N. A hybrid variable step size MPPT method based on P\&O and INC methods. In Proceedings of the 2017 10th International Conference on Electrical and Electronics Engineering (ELECO), Bursa, Turkey, 30 November-2 December 2017; pp. 949-953.

130. Jiang, L.L.; Nayanasiri, D.; Maskell, D.L.; Vilathgamuwa, D. A hybrid maximum power point tracking for partially shaded photovoltaic systems in the tropics. Renew. Energy 2015, 76, 53-65. [CrossRef]

131. Karatepe, E.; Hiyama, T. Artificial neural network-polar coordinated fuzzy controller based maximum power point tracking control under partially shaded conditions. IET Renew. Power Gener. 2009, 3, 239-253.

132. Lashab, A.; Sera, D.; Martins, J.; Guerrero, J.M. Multilevel DC-link converter-based photovoltaic system with integrated energy storage. In Proceedings of the 2018 5th International Symposium on Environment-Friendly Energies and Applications (EFEA), Rome, Italy, 24-26 September 2018; pp. 1-6.

133. Zhao, W.; Choi, H.; Konstantinou, G.; Ciobotaru, M.; Agelidis, V.G. Cascaded H-bridge multilevel converter for large-scale PV grid-integration with isolated DC-DC stage. In Proceedings of the 2012 3rd IEEE International Symposium on Power Electronics for Distributed Generation Systems (PEDG), Aalborg, Denmark, 25-28 June 2012; pp. 849-856.

134. Jain, S.; Sonti, V. A Highly Efficient and Reliable Inverter Configuration Based Cascaded Multilevel Inverter for PV Systems. IEEE Trans. Ind. Electron. 2017, 64, 2865-2875. [CrossRef]

135. Lashab, A.; Sera, D.; Hahn, F.; Camurca, L.; Terriche, Y.; Liserre, M.; Guerrero, J.M. Cascaded Multilevel PV Inverter with Improved Harmonic Performance during Power Imbalance Between Power Cells. IEEE Trans. Ind. Appl. 2020, 56, 2788-2798. [CrossRef]

136. Shen, K.; Zhao, D.; Zhao, G.; Wang, S. Photovoltaic supplied grid-connected modular multilevel converter with active power injection and reactive power compensation capability. In Proceedings of the IECON 2017-43rd Annual Conference of the IEEE Industrial Electronics Society, Beijing, China, 29 October-1 November 2017; pp. 7837-7842.

137. Behera, R.R.; Thakur, A.N. Hybrid modular multilevel converter based single-phase Grid connected photovoltaic system. Int. J. Renew. Energy Res. 2017, 7, 1245-1249.

138. Bettawar, P.A.; Punam, S.R. A Comparative Study of Different Multilevel Converter Topologies for High Power Photovoltaic Applications. In Proceedings of the the 2016 7th Power Electronics and Drive Systems Technologies Conference (PEDSTC), Tehran, Iran, 16-18 February 2016.

139. Jiang, X.; Doumbia, M.L. Comparative Study of Grid-Connected Multilevel Inverters for High Power Phtovoltaic Systems. In Proceedings of the IEEE 7th International Conference on Smart Energy Grid Engineering (SEGE), Oshawa, ON, Canada, 12-14 August 2019; pp. 184-190.

140. Vahedi, H.; Sharifzadeh, M.; Al-Haddad, K. Modified seven-level pack U-cell inverter for photovoltaic applications. IEEE J. Emerg. Sel. Top. Power Electron. 2018, 6, 1508-1516. [CrossRef]

141. Abdoli, H.; Khorsandi, A.; Eskandari, B.; Moghani, J.S. A new reduced switch multilevel inverter for pv applications. In Proceedings of the 11th Power Electronics, Drive Systems, and Technologies Conference (PEDSTC), Tehran, Iran, 4-6 February 2020; pp. 1-5.

142. Hamidi, M.N.; Ishak, D.; Zainuri, M.A.A.M.; Ooi, C.A. An asymmetrical multilevel inverter with optimum number of components based on new basic structure for photovoltaic renewable energy system. Sol. Energy 2020, 204, 13-25. [CrossRef]

143. Agrawal, R.; Jain, S. Comparison of reduced part count multilevel inverters (RPC-MLIs) for integration to the grid. Int. J. Electr. Power Energy Syst. 2017, 84, 214-224. [CrossRef]

144. Xiao, B.; Tolbert, L.M. Efficiency improved and current balanced three-phase modular cascaded H-bridge multilevel PV inverter for grid-connected applications. In Proceedings of the 2014 IEEE Energy Conversion Congress and Exposition (ECCE), Pittsburgh, PA, USA, 14-18 September 2014; pp. 4661-4669. [CrossRef]

145. Bana, P.R.; Panda, K.P.; Naayagi, R.; Siano, P.; Panda, G. Recently developed reduced switch multilevel inverter for renewable energy integration and drives application: Topologies, comprehensive analysis and comparative evaluation. IEEE Access 2019, 7, 54888-54909. [CrossRef]

146. Alhamrouni, I.; Rahmat, M.K.; Ismail, F.A.; Salem, M.; Jusoh, A.; Sutikno, T. Design and development of SEPIC DC-DC boost converter for photovoltaic application. Int. J. Pow. Elec. Dri. Syst. 2019, 1, 406-413. [CrossRef]

147. Basu, T.S.; Maiti, S. A hybrid modular multilevel converter for solar power integration. IEEE Trans. Ind. Appl. 2019, 55, 5166-5177. [CrossRef]

148. Mahfuz-Ur-Rahman, A.; Islam, M.R.; Muttaqi, K.M.; Sutanto, D. Model Predictive Control for a New Magnetic Linked Multilevel Inverter to Integrate Solar Photovoltaic Systems With the Power Grids. IEEE Trans. Ind. Appl. 2020, 56, 7145-7155. [CrossRef] 
149. Bana, P.R.; Panda, K.P.; Padmanaban, S.; Mihet-Popa, L.; Panda, G.; Wu, J. Closed-loop control and performance evaluation of reduced part count multilevel inverter interfacing grid-connected PV system. IEEE Access 2020, 8, 75691-75701. [CrossRef]

150. Taghvaie, A.; Haque, M.E.; Saha, S.; Mahmud, M.A. A new step-up switched-capacitor voltage balancing converter for NPC multilevel inverter-based solar PV system. IEEE Access 2020, 8, 83940-83952. [CrossRef]

151. Tayari, M.; Guermazi, A.; Ghariani, M. Cascaded Multilevel Inverter for PV-Active Power Filter Combination into the Grid-Tied Solar System. Int. J. Renew. Energy Res. 2020, 10, 1810-1819.

152. Keddar, M.; Doumbia, M.L.; Della, M.; Belmokhtar, K.; Midoun, A. Interconnection Performance Analysis of Single Phase Neural Network Based NPC and CHB Multilevel Inverters for Grid-connected PV Systems. Int. J. Renew. Energy Res. 2019, 9, 1451-1461.

153. Sharma, B.; Nakka, J. Single-phase cascaded multilevel inverter topology addressed with the problem of unequal photovoltaic power distribution in isolated dc links. IET Power Electron. 2018, 12, 284-294. [CrossRef]

154. Xiao, B.; Hang, L.; Mei, J.; Riley, C.; Tolbert, L.M.; Ozpineci, B. Modular cascaded H-bridge multilevel PV inverter with distributed MPPT for grid-connected applications. IEEE Trans. Ind. Appl. 2014, 51, 1722-1731. [CrossRef]

155. Kumar, A.; Verma, V. Performance enhancement of single-phase grid-connected PV system under partial shading using cascaded multilevel converter. IEEE Trans. Ind. Appl. 2018, 54, 2665-2676. [CrossRef]

156. Karthikeyan, D.; Vijayakumar, K.; Sathik, J. Generalized cascaded symmetric and level doubling multilevel converter topology with reduced THD for photovoltaic applications. Electronics 2019, 8, 161.

157. Kadam, A.; Shukla, A. A multilevel transformerless inverter employing ground connection between PV negative terminal and grid neutral point. IEEE Trans. Ind. Electron. 2017, 64, 8897-8907. [CrossRef]

158. Xiao, H.F.; Liu, X.P.; Lan, K. Zero-voltage-transition full-bridge topologies for transformerless photovoltaic grid-connected inverter. IEEE Trans. Ind. Electron. 2014, 61, 5393-5401. [CrossRef]

159. Ji, B.; Wang, J.; Zhao, J. High-efficiency single-phase transformerless PV H6 inverter with hybrid modulation method. IEEE Trans. Ind. Electron. 2013, 60, 2104-2115. [CrossRef]

160. Guo, X.; Jia, X. Hardware-based cascaded topology and modulation strategy with leakage current reduction for transformerless PV systems. IEEE Trans. Ind. Electron. 2016, 63, 7823-7832. [CrossRef]

161. Kukade, P.; Sonti, V.; Jain, S. A cascaded HERIC based multilevel inverter for reducing leakage current in the PV applications. In Proceedings of the IECON -43rd Annual Conference of the IEEE Industrial Electronics Society, Beijing, China, 29 October-1 November 2017; pp. 4203-4208.

162. Valderrama, G.E.; Guzman, G.V.; Pool-Mazún, E.I..; Martinez-Rodriguez, P.R.; Lopez-Sanchez, M.J.; Zuñiga, J.M.S. A single-phase asymmetrical T-type five-level transformerless PV inverter. IEEE J. Emerg. Sel. Top. Power Electron. 2018, 6, 140-150. [CrossRef]

163. Grigoletto, F.B. Five-level transformerless inverter for single-phase solar photovoltaic applications. IEEE J. Emerg. Sel. Top. Power Electron. 2019, 8, 3411-3422. [CrossRef]

164. Shaffer, B.; Hassan, H.A.; Scott, M.J.; Hasan, S.U.; Town, G.E.; Siwakoti, Y. A common-ground single-phase five-level transformerless boost inverter for photovoltaic applications. In Proceedings of the IEEE Applied Power Electronics Conference and Exposition (APEC), San Antonio, TX, USA, 4-8 March 2018; pp. 368-374.

165. Li, W.; Gu, Y.; Luo, H.; Cui, W.; He, X.; Xia, C. Topology review and derivation methodology of single-phase transformerless photovoltaic inverters for leakage current suppression. IEEE Trans. Ind. Electron. 2015, 62, 4537-4551. [CrossRef]

166. Yue, X.; Wang, H.; Zhu, X.; Wei, X.; Liu, Y.-F. A Topology Synthetization Method for Single-Phase, Full-Bridge, Transformerless Inverter with Leakage Current Suppression-Part II. Energies 2020, 13, 446. [CrossRef]

167. Sonti, V.; Dhara, S.; Kukade, P.; Jain, S.; Agarwal, V. Analysis for the minimization of leakage and common mode currents in cascaded half-bridge PV fed multilevel inverter. IEEE J. Emerg. Sel. Top. Power Electron. 2018, 7, 2443-2452. [CrossRef]

168. Zhu, X.; Wang, H.; Sun, R.; Wang, H.; Zhang, W.; Deng, X.; Yue, X. Leakage Current Suppression of Single-Phase Five-Level Inverter for Transformer-less PV System. IEEE Trans. Ind. Electron. 2020. [CrossRef]

169. Venkatramanan, D.; John, V. A modified common-mode filter with enhanced attenuation performance in single-phase grid-tied solar pv inverters. In Proceedings of the IEEE International Conference on Power Electronics, Smart Grid and Renewable Energy (PESGRE2020), Cochin, India, 2-4 January 2020; pp. 1-6.

170. Jebaselvi, G.A.; Paramasivam, S. Analysis on renewable energy systems. Renew. Sustain. Energy Rev. 2013, 28, 625-634. [CrossRef]

171. Kurtoğlu, M.; Eroğlu, F.; Arslan, A.O.; Vural, A.M. Recent contributions and future prospects of the modular multilevel converters: A comprehensive review. Int. Trans. Electr. Energy Syst. 2019, 29, e2763. [CrossRef]

172. Zhang, L.; Zou, Y.; Yu, J.; Qin, J.; Vittal, V.; Karady, G.G.; Shi, D.; Wang, Z. Modeling, control, and protection of modular multilevel converter-based multi-terminal HVDC systems: A review. CSEE J. Power Energy Syst. 2017, 3, 340-352. [CrossRef]

173. Huang, J.; Yang, B.; Guo, F.; Wang, Z.; Tong, X.; Zhang, A.; Xiao, J. Priority Sorting Approach for Modular Multilevel Converter Based on Simplified Model Predictive Control. IEEE Trans. Ind. Electron. 2018, 65, 4819-4830. [CrossRef]

174. Priya, M.; Ponnambalam, P.; Muralikumar, K. Modular-multilevel converter topologies and applications-a review. IET Power Electron. 2018, 12, 170-183. [CrossRef]

175. Mao, M.; Cui, L.; Zhang, Q.; Guo, K.; Zhou, L.; Huang, H. Classification and summarization of solar photovoltaic MPPT techniques: A review based on traditional and intelligent control strategies. Energy Rep. 2020, 6, 1312-1327. [CrossRef] 